\title{
Carbon- and oxygen-isotope stratigraphy of the English Chalk and Italian Scaglia and its palaeoclimatic significance
}

\author{
H. C. JENK YNS*, A. S. GALE† \& R. M. CORFIELD* \\ * Department of Earth Sciences, University of Oxford, Parks Road, Oxford OX1 3PR, UK \\ † Department of Geology, Imperial College, Prince Consort Road, London SW7 2BP, UK and Department of \\ Palaeontology, the Natural History Museum, Cromwell Road, London SW7 5BD, UK
}

(Received 24 November 1992; revised version received, accepted 23 August 1993)

\begin{abstract}
A detailed carbon- and oxygen-isotope stratigraphy has been generated from Upper Cretaceous coastal Chalk sections in southern England (East Kent; Culver Cliff, Isle of Wight; Eastbourne and Seaford Head, Sussex; Norfolk Coast) and the British Geological Survey (BGS) Trunch borehole, Norfolk. Data are also presented from a section through the Scaglia facies exposed near Gubbio, Italian Apennines. Wherever possible the sampling interval has been one metre or less. Both the Chalk and Scaglia carbon-isotopic curves show minor positive excursions in the midCenomanian, mid- and high Turonian, basal Coniacian and highest Santonian-lowest Campanian; there is a negative excursion high in the Campanian in Chalk sections that span that interval. The well-documented Cenomanian-Turonian boundary 'spike' is also well displayed, as is a broad positive excursion centred on the upper Coniacian. A number of these positive excursions correlate with records of organic-carbon-rich deposition in the Atlantic Ocean and elsewhere. The remarkable similarity in the carbon-isotope curves from England and Italy enables cross-referencing of macrofossil and microfossil zones and pinpoints considerable discrepancy in the relative positions of the Turonian, Coniacian and Santonian stages.

The oxygen-isotope values of the various Chalk sections, although showing different absolute values that are presumably diagenesis-dependent, show nonetheless a consistent trend. The East Kent section, which is very poorly lithified, indicates a warming up to the Cenomanian-Turonian boundary interval, then cooling thereafter. Regional organic-carbon burial, documented for this period, is credited with causing drawdown of $\mathrm{CO}_{2}$ and initiating climatic deterioration (inverse greenhouse effect). Data from other parts of the world are consistent with the hypothesis that the Cenomanian-Turonian temperature optimum was a global phenomenon and that this interval represents a major turning point in the climatic history of the earth.
\end{abstract}

\section{Introduction}

The Chalk is largely composed of calcareous nannofossils, together with subsidiary amounts of planktonic and benthonic foraminifera, pithonellids (calcispheres), a range of calcitic macrofossil debris, of which bivalve (e.g. Inoceramidae), bryozoan and echinoid remains are generally prominent components (Bromley, 1979) and clay minerals, chiefly illite and smectite, plus traces of detrital quartz, phosphatic and glauconitic material and pyrite (Håkansson, Bromley \& Perch-Nielsen, 1974; Scholle, 1974; Hancock, 1975; Pacey, 1984). Cement generally takes the form of minor overgrowths on coccoliths. Porosities are typically in the range of $27-46 \%$, permeabilities in the range of 2 to $12 \mathrm{md}$; lower figures of both these parameters are typical for sediments of the more clayrich Lower Chalk.

This characteristic deposit is generally interpreted as a pelagic shelf-sea sediment deposited during a particularly high stand of relative sea level in the European and other areas. Indeed sequence-stratigraphic evidence suggests that the highest eustatic sea level in the Phanerozoic may have been achieved during the early Turonian when chalk deposition was widespread across much of northern Europe (Vail, Mitchum \& Thompson, 1977; Haq, Hardenbol \& Vail, 1988), although details of changing chalk-sea bathymetry with time remain controversial and significant discrepancies exist between the Western Interior of the United States and northern Europe (Hancock \& Kauffman, 1979; Hancock, 1989).

The first detailed carbon- and oxygen-isotope stratigraphy of the English Chalk was undertaken by Scholle \& Arthur (1980). Their pioneering studies of Chalk sections from Dover/Folkestone, Norfolk and the Isle of Wight, together with data from the Netherlands, Germany and the North Sea, showed the stratigraphic variance of carbon isotopes through the Cenomanian to Campanian stages of the Cretaceous. A comparable isotopic profile was identified from the Scaglia facies of the Italian Apennines. A striking feature of their curves from the English Chalk was a positive $\delta^{13} \mathrm{C}$ excursion or 'spike' at the Cenomanian-Turonian boundary and much subsequent work has centred on detailed investigation of this interval, in terms of both isotopic and other geochemistry, faunal change and associated sedi- 
mentary anomalies (Pratt \& Threlkeld, 1984; Jenkyns, 1985; Hilbrecht \& Hoefs, 1986; Bralower, 1988; Brumsack \& Thurow, 1986; Jarvis et al. 1988; Kuhnt et al. 1986; Corfield, Hall \& Brasier, 1990; Pratt, Force \& Pomerol, 1991; Pratt et al. in press). Chief amongst the latter are the carbon-rich shales that characterize this interval, not only in parts of the English succession, but also in diverse regions of the globe including northern and southern Europe, Africa, North and South America, the western margin of Australia and the Pacific and Atlantic basins (Schlanger \& Jenkyns, 1976; Jenkyns, 1980; Herbin et al. 1986; Schlanger et al. 1987; Lipson-Benitah et al. 1990; Kuhnt et al. 1986, 1990; Crumière et al. 1990; von Rad et al. 1989; Jenkyns, 1991).

Positive shifts in carbon-isotope values in biogenic carbonates are conventionally interpreted in terms of local or regional burial patterns of organic carbon and/or changes in surface-water productivity; the former mechanism is probably the more significant (Gale et al. 1993). Since organic carbon is preferentially enriched in the lighter isotope ${ }^{12} \mathrm{C}$, its removal from the oceanic reservoir and escape from oxidative recycling renders ocean waters relatively enriched in ${ }^{13} \mathrm{C}$ (see, e.g. Scholle \& Arthur, 1980; Weissert, 1989). Hence the anomalously high rates of preservation of organic carbon in a variety of environments around the world at the Cenomanian-Turonian boundary can be genetically linked to the carbon-isotope excursion. These phenomena have been taken as evidence for a global or quasi-global 'oceanic anoxic event' (Schlanger \& Jenkyns, 1976; Jenkyns, 1980; Schlanger et al. 1987) during which oceanographic conditions were peculiarly favourable for the deposition of black shales and allied carbon-rich lithologies.

Also just discernible in the isotopic profiles of Scholle \& Arthur (1980) from Dover/Folkestone is an increase in carbon-isotope ratios $\left(\delta^{13} \mathrm{C}\right)$ in the Coniacian interval. In an attempt to provide more detailed coverage of this and adjacent stages, particularly as Coniacian carbon-rich shales occur in several deepsea drilling sites in the Atlantic (Ryan \& Cita, 1977; Arthur \& Natland, 1979), we began sampling a number of chalk sections at a regular interval of one metre, in relation to bed-scale lithostratigraphy, wherever exposure permitted. As we progressed, it became clear that not only were the carbon-isotope values of interest but so also were the oxygen-isotope values; we hence extended our coverage to include all relevant outcrop material and the Trunch borehole which offers a more complete Campanian and lower Maastrichtian section than is available in coastal outcrops. Sample spacing in this borehole also approximated to one metre wherever recovery permitted. We have thus assembled the most detailed oxygen- and carbon-isotope stratigraphy for the English Chalk currently available. In addition, to compare the isotopic signals so obtained with those from a pelagic-carbonate section deriving from a different palaeogeographic domain, we collected and analysed Scaglia facies sampled at one metre spacing or less through the Cenomanian-Maastrichtian interval from the Bottaccione Gorge close to Gubbio, Marche-Umbria, Italy. Sampling was more dense in the mid-Cenomanian and close to the boundary with the overlying Turonian stage. The resulting data confirm and amplify the recently published isotope stratigraphy of Corfield et al. (1991), with the advantage of being derived from more closely spaced samples and set against a detailed stratigraphical and lithological section.

\section{Analytical techniques}

In the case of the Chalk, samples were obtained by scraping sufficient material from hand specimens; analyses from different positions within 11 hand specimens tested typically differed by less than $0.5 \%$ for $\delta^{18} \mathrm{O}$ and $0.2 \%$ for $\delta^{13} \mathrm{C}$. The Scaglia samples from Gubbio, which are completely lithified, were initially selected to avoid material containing stylolites and calcite veins. They were then crushed to homogenize the samples, as multiple analyses across individual hand specimens showed considerable variation (up to $3 \%$ for $\delta^{18} \mathrm{O}$ and $1.5 \%$ for $\delta^{13} \mathrm{C}$ ), a phenomenon previously demonstrated by Jenkyns \& Clayton (1986) for Jurassic pelagic limestones from the AlpineMediterranean region. Replicate analyses on the powders showed reproducibility virtually on a par with those of standards.

Samples were then cleaned using $10 \% \quad \mathrm{H}_{2} \mathrm{O}_{2}$ followed by acetone and then dried at $60^{\circ} \mathrm{C}$. They were then reacted with purified orthophosphoric acid at $90^{\circ} \mathrm{C}$ and analysed on-line using a VG Isocarb device and Prism mass spectrometer at Oxford University. Normal corrections were applied and the results are reported, using the usual $\delta$ notation, in \% deviation from the PDB (Pee Dee Belemnite) standard. Calibration to PDB was performed via our laboratory standard calibrated against NBS19 and Cambridge Carrara marble. Reproducibility of replicate analyses of standards was generally better than $0.1 \%$ for both carbon- and oxygen-isotope ratios.

\section{The stratigraphy of the English Chalk}

Ammonites provide the most refined and widely recognized subdivisions of the marine Upper Cretaceous and about 25 zones are now identified (Hancock, 1991). However, for most of the postCenomanian Chalk succession in England, ammonites are absent or extremely rare, probably as a consequence of the early diagenetic solution of aragonite (Hudson, 1967; Kennedy, 1969), and a local biostratigraphy has been developed using benthonic fossils composed of calcite. Largely following the 
work of Rowe $(1899,1900,1908)$ the Middle and Upper Chalk have been subdivided into macrofossil assemblage zones based on echinoderms, belemnites, bivalves and brachiopods (Rawson et al. 1978; Gale \& Cleevely, 1989). Zones may reach a maximum thickness of over $100 \mathrm{~m}$ and thus provide a coarse subdivision of the Chalk; the boundaries, however, are often difficult to define, especially in core.

Over the past 15 years, various workers have erected lithostratigraphical schemes for different geographical regions of the English Chalk outcrop (Wood \& Smith, 1978 for Yorkshire and Lincolnshire; Jarvis \& Woodroof, 1984, and Jarvis \& Tocher, 1987 for Devon; Mortimore, 1983, 1986 for Sussex; Robinson, 1986 for Kent and Surrey). These papers were reviewed by Gale, Wood \& Bromley (1987) who proposed a compromise classification applicable to the White Chalk Formation (= Middle and Upper Chalk) of southern England, from Kent to Devon (Fig. 3). The underlying Lower Chalk Formation contains four members (Glauconitic Marl, Chalk Marl, Grey Chalk, Plenus Marls). In the BGS Trunch borehole in northeast Norfolk, the terms Middle and Upper Chalk are provisionally retained (Arthurton et al. in press).

The work of Jefferies $(1962,1963)$ on the Plenus Marls demonstrated the wide persistence of this faunal and lithological marker bed or beds across the AngloParis Basin. Subsequent workers have found that levels of chert nodules (flint), marl seams and hardgrounds are also developed regionally (Bromley \& Gale, 1982; Mortimore, 1986; Mortimore \& Wood,

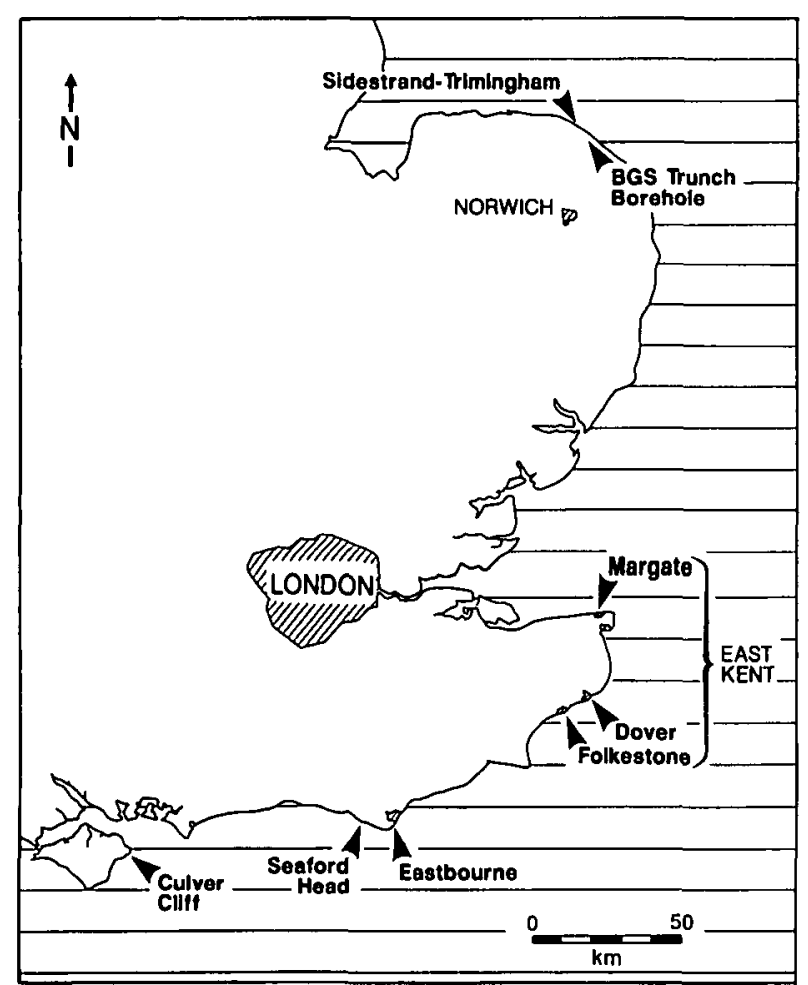

Figure 1. Map of southeast England to illustrate the sampling localities.

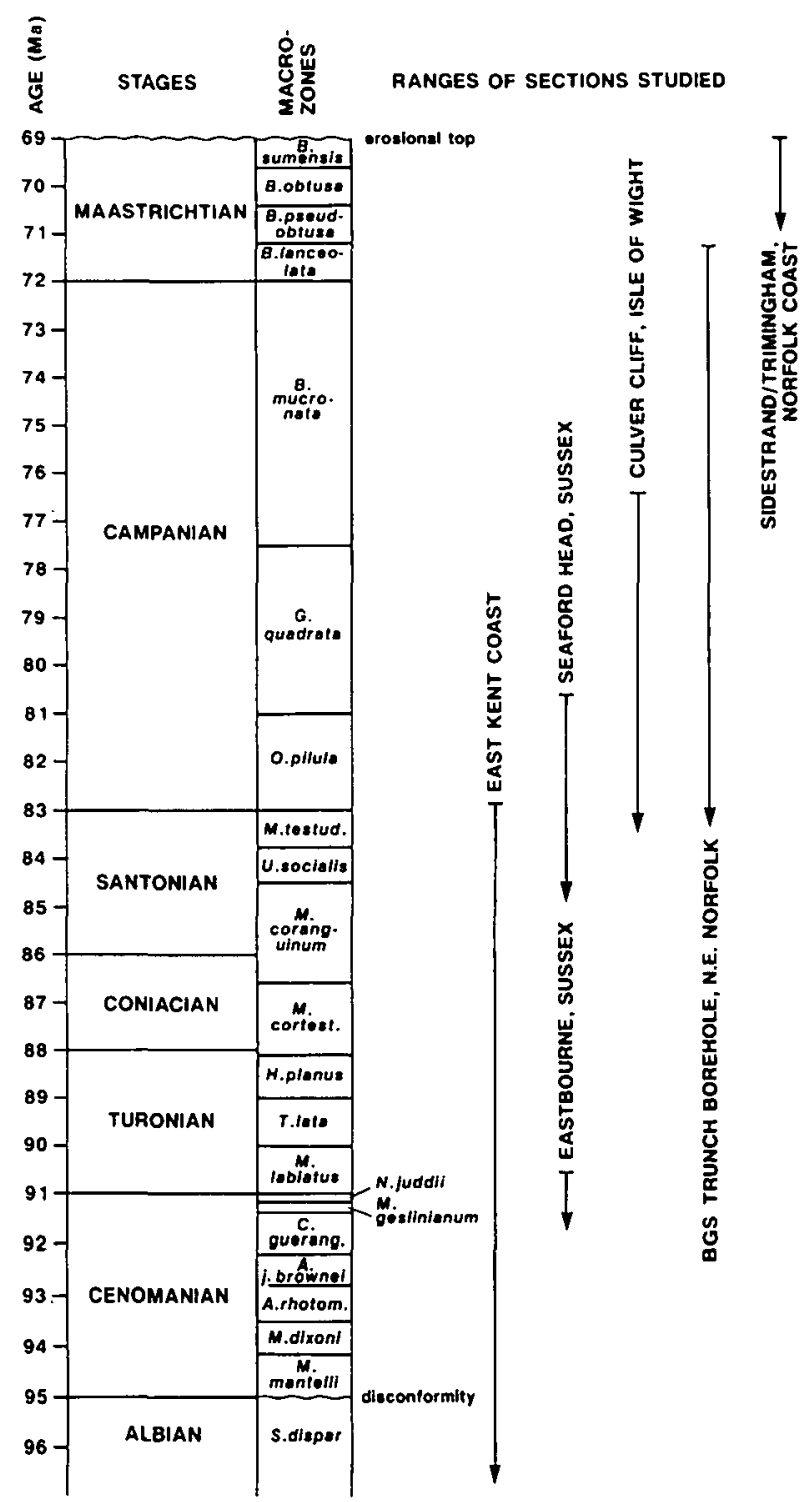

Figure 2. Stratigraphical nomenclature of Upper Cretaceous sediments in southeast England, and the ranges of the sampled sections. Time scale after Kennedy \& Odin (1982).

1986; Robinson, 1986) and are of stratigraphic worth, permitting high-resolution correlation over large areas. In the Lower Chalk, chalk-marl couplets provide the basis for a decimetre-scale correlation (Gale, 1989).

The English Chalk has been the subject of extensive micropalaeontological study over several decades, and foraminiferans have proven particularly useful stratigraphically, although international index planktonic species are rare or absent through much of the section (Carter \& Hart, 1977; Bailey \& Hart, 1979; Hart et al. 1989). Calcareous nannofossils have been described by Crux (1982) and Burnett et al. (unpub. data). Unfortunately, much of the micropalaeontological sampling has not been related to detailed lithological successions. Inoceramid bivalves are of considerable value for inter-regional and even global correlation of Upper Cretaceous marine sediments 
(Tröger, 1989). Although incompletely studied in the English succession, we include data on their distribution from Bailey et al. $(1983,1984)$ and Wood \& Gale (unpub. data).

The location of sample sites is shown in Figure 1, and comparative stratigraphical ranges of the sections sampled are shown in Figure 2. Smaller-scale summary sections which show key marker beds and the available biostratigraphical data on different fossil groups are given in Figs 3-9 and large scale stratigraphical logs are provided for the East Kent, Culver and Seaford sections (Figs 13, 14, 15 in Appendix).

\section{3.a. East Kent (Cenomanian-lower Campanian)}

Cliff-sections on the east Kent coast provide extensive exposure of gently dipping Cenomanian to lowest Campanian Chalk which has experienced only modest burial depths (estimated as about $500 \mathrm{~m}$ ), and is for the main part easily accessible on cliff-paths (Figs 1; 13 in Appendix). Early descriptions of the lithological succession by Phillips (1821) were followed by more detailed accounts of the stratigraphy of the Lower Chalk by Price (1877) and zonation of the Middle and Upper (White) Chalk by Rowe (1900). The stratigraphy of the Plenus Marls was described in detail by Jefferies $(1962,1963)$, that of the Lower Chalk by Kennedy (1969) and Gale (1989). Jarvis et al. (1988) provided a detailed account of the CenomanianTuronian boundary interval at Dover.

Robinson (1986) published a very detailed lithostratigraphical nomenclature of the Middle and Upper Chalk of previous authors, and correlated the coastal sections with quarries on the North Downs. Many of his marker beds are correlative with those in the South Downs, named previously by Mortimore (1983), and the latter are preferred where correlation is well established.

We are unable to assign the foraminiferal zones established in east Kent by Hart et al. (1989) to our lithological sections of the same region with any certainty as their published logs (Hart et al. 1989, Figs 7.10-7.12) show few recognizable marker beds. The nannofossil zonation presented here is taken from Burnett et al. (unpub. data), and the macrofossil zonation follows Gale (1989) for the Lower Chalk and Bailey et al. (1983, 1984) and Wood \& Gale (unpub. data) for the White Chalk.

A thick succession of Lower Chalk crops out between Folkestone and Dover (Fig. 1); the Glauconitic Marl and lower part of the Chalk Marl are only exposed in the Warren landslip foreshore (Gale, 1989). At the base of the White Chalk, the Shakespeare Cliff Member (uppermost Cenomanian-lower Turonian), is strongly condensed relative to Sussex and developed in nodular facies rich in inoceramid debris. The middle Turonian Ranscombe Chalk is stratigraphically expanded in soft-chalk facies on the Kent coast, but the overlying St Margaret's Chalk (upper Turonian-mid-Coniacian) is thin and contains many hardgrounds and nodular chalks. The Broadstairs Chalk (Coniacian-Santonian), cropping out to the east of Margate (Fig. 1), is a very soft nannofossil chalk with numerous horizons of chert/flint nodules, including distinctive marker flints, such as Whitaker's 3 -inch Flint. The upper Santonian is represented by a thin development of very soft, almost flintless chalk, the Margate Member.

The Lower Chalk was sampled on the coast between Folkestone and Dover, on the foreshore in East Wear Bay (TR 261383), at Abbot's Cliff (TR 271385279386), and between Hay Cliff (TR 302395) and Shakespeare Cliff, west of Dover (TR 308398). The lower part of the White Chalk was sampled on Aker's Steps, west of Dover (TR 297394), and east of Dover at Langdon Stairs (TR 345424). The higher part of the Broadstairs Chalk was sampled south of Kingsdown (TR 381471-381476), and on the North Foreland, north of Broadstairs (TR 399701-402695). The highest Chalk was sampled at Kingsgate (TR 396710) and Foreness Point (TR 383717).

The carbon- and oxygen-isotope stratigraphy for these sections is illustrated in Figures 3 and 4.

\section{3.b. Eastbourne, Sussex (Cenomanian-Turonian)}

Cliff sections at Holywell (TV 603973) and Gun Gardens (TV 588964) west of Eastbourne (Fig. 1) display the most expanded developments of upper Cenomanian and lower Turonian strata cropping out in the Anglo-Paris Basin (Jefferies, 1963; Mortimore, 1986; Gale et al. 1993). At this locality, the highest part of the Grey Chalk shows rhythmic alternations of more and less clay-rich chalk, overlain: by up to $5.5 \mathrm{~m}$ of Plenus Marls. The lower part of the White Chalk above consists of beds of hard, locally nodular and intraclastic chalk including a distinctive suite of marl seams (Meads and Holywell marls). It is possible to recognize here the ammonite zones at the Cenomanian-Turonian boundary present in the western interior of the United States (Kennedy \& Cobban, 1991). The carbon- and oxygen-isotope stratigraphy of the stage boundary in this section is shown in Figure 5.

\section{3.c. Seaford Head, Sussex (Santonian-Campanian)}

Seaford Head (Fig. 1) is situated immediately to the east of the town of Seaford on the Sussex coast (TV 491578), and at low tide provides continuous outcrop of upper Turonian to lower Campanian Chalk. The section was zoned by Rowe (1900), and the lithological succession has been described by Mortimore (1986, 1987) who named numerous marker flints and marls. We have sampled only the upper Santonian to lower 


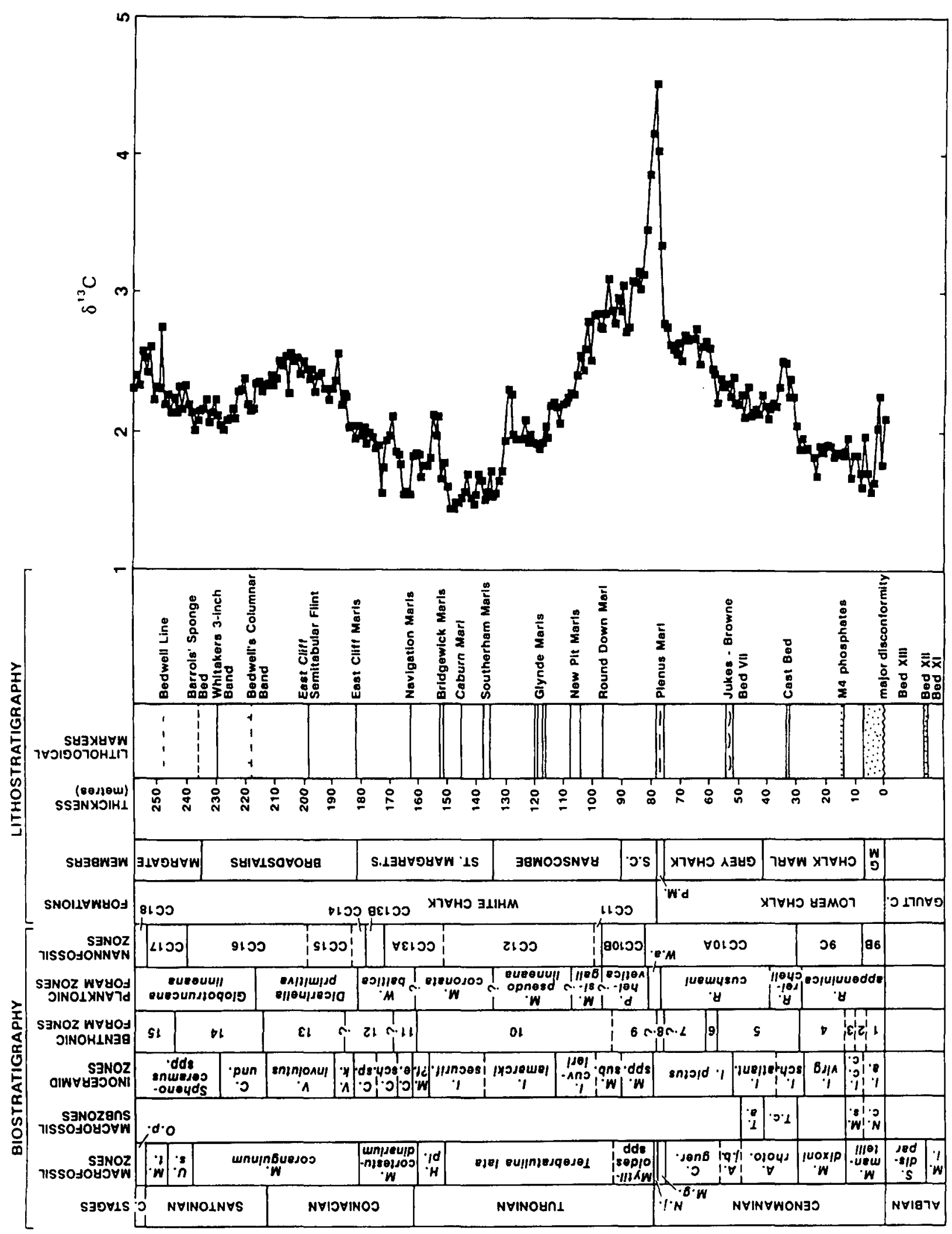

ชิธ์

窟

定

$\div 8$

可

可

㐘

可

鬲.

궁

政

\&

5.

ษั

s

苛芯芯

형

政

을

政

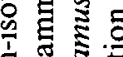

등

령용

咹

(5)

要

过

궁응

污

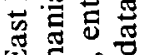

응.

U⿺辶

它

ह

迹

․․․․․

동ㅇㅇㅇ

1 I

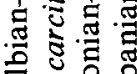

邻

\%

응

.

के

बํํㅇ

䆛

츈

क

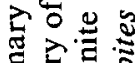

政言

망묘 


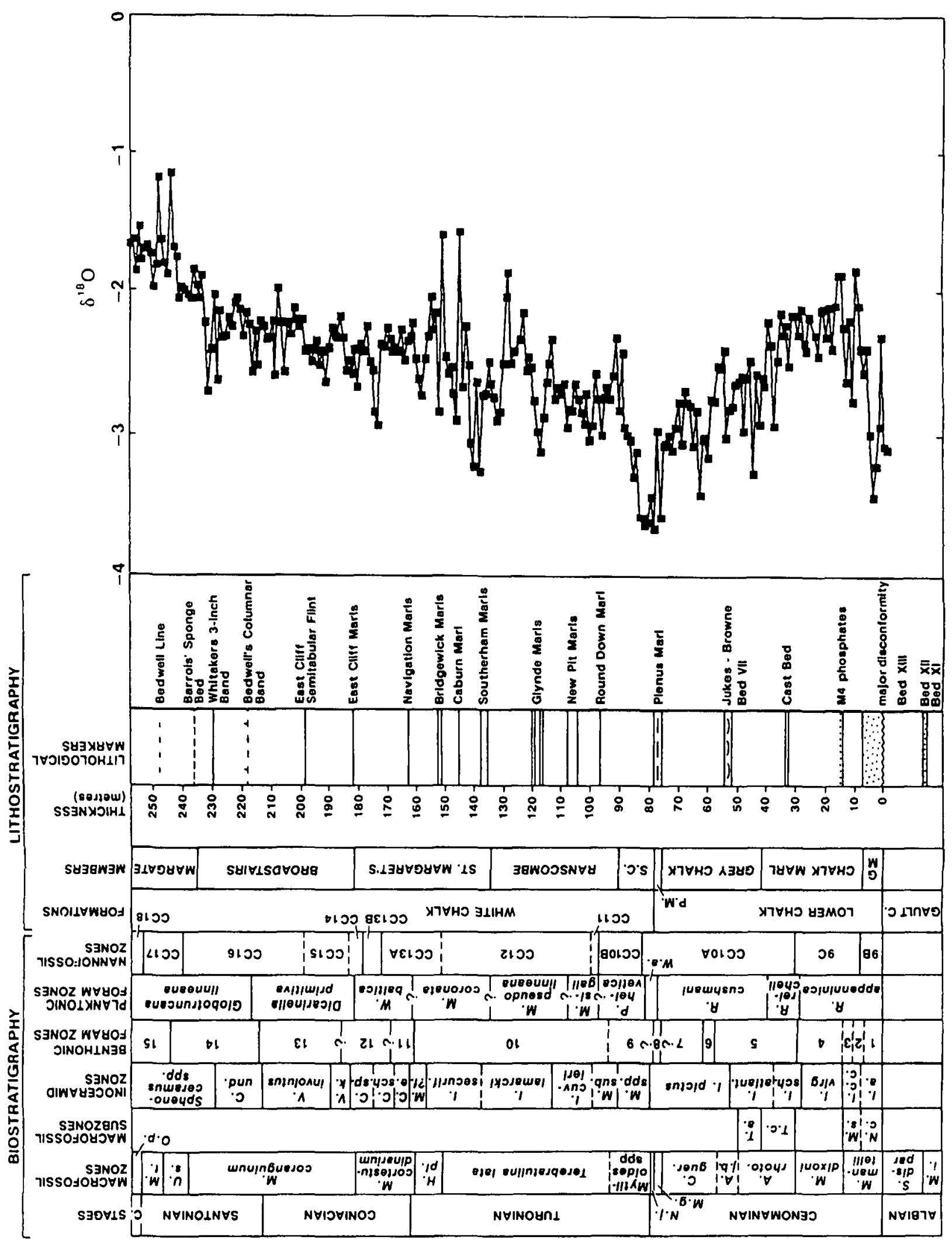




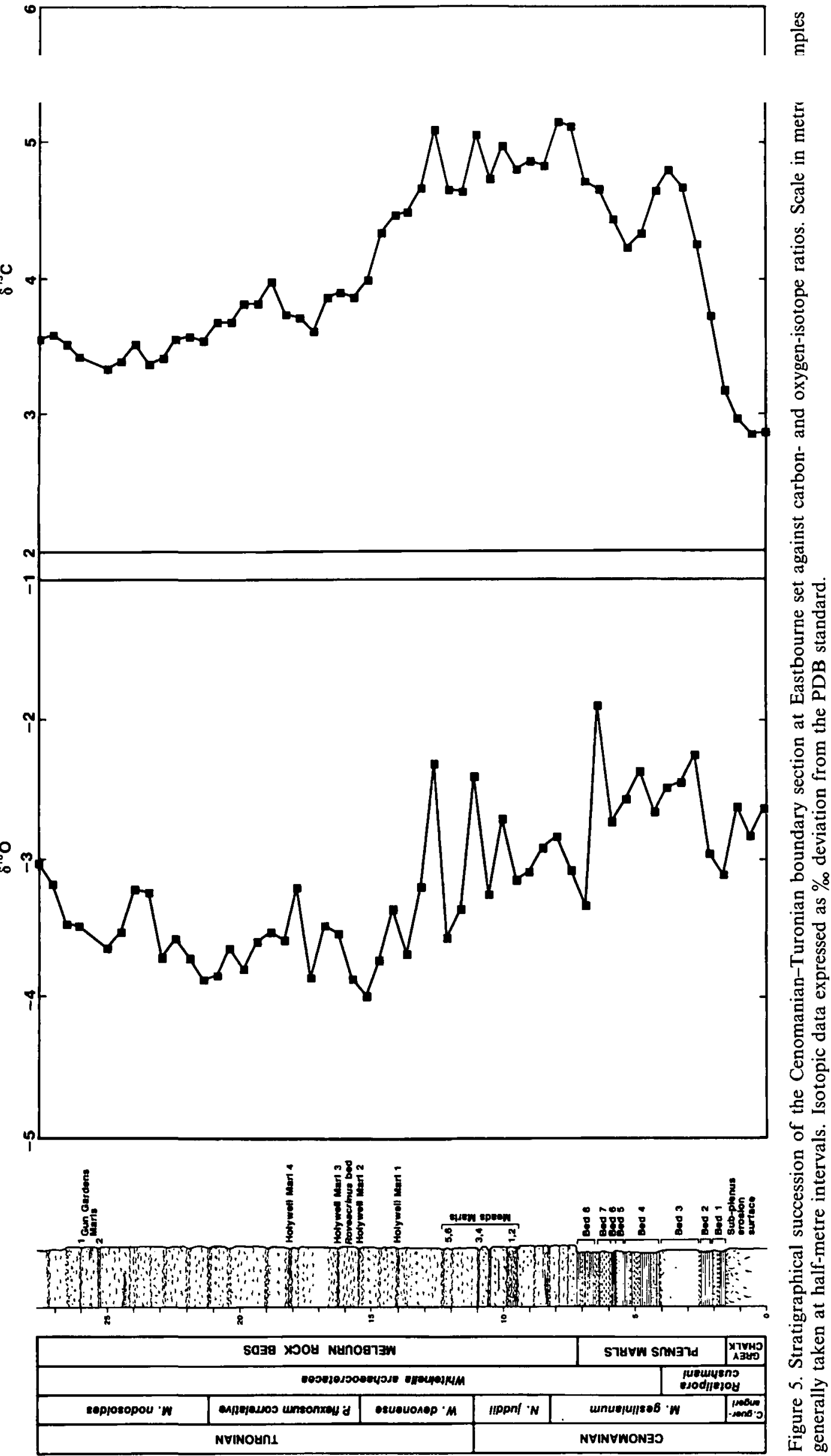




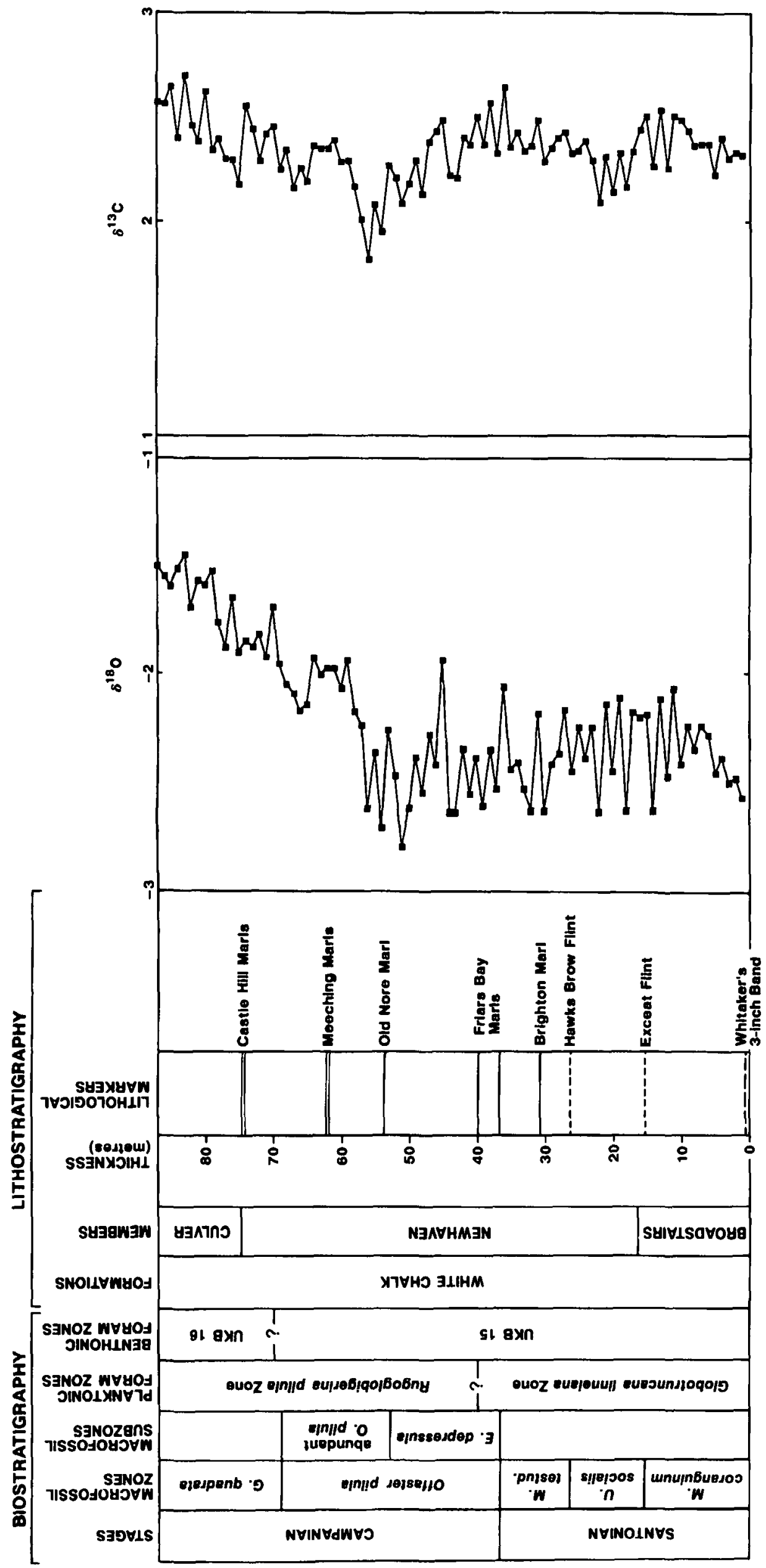

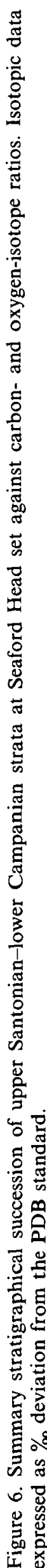




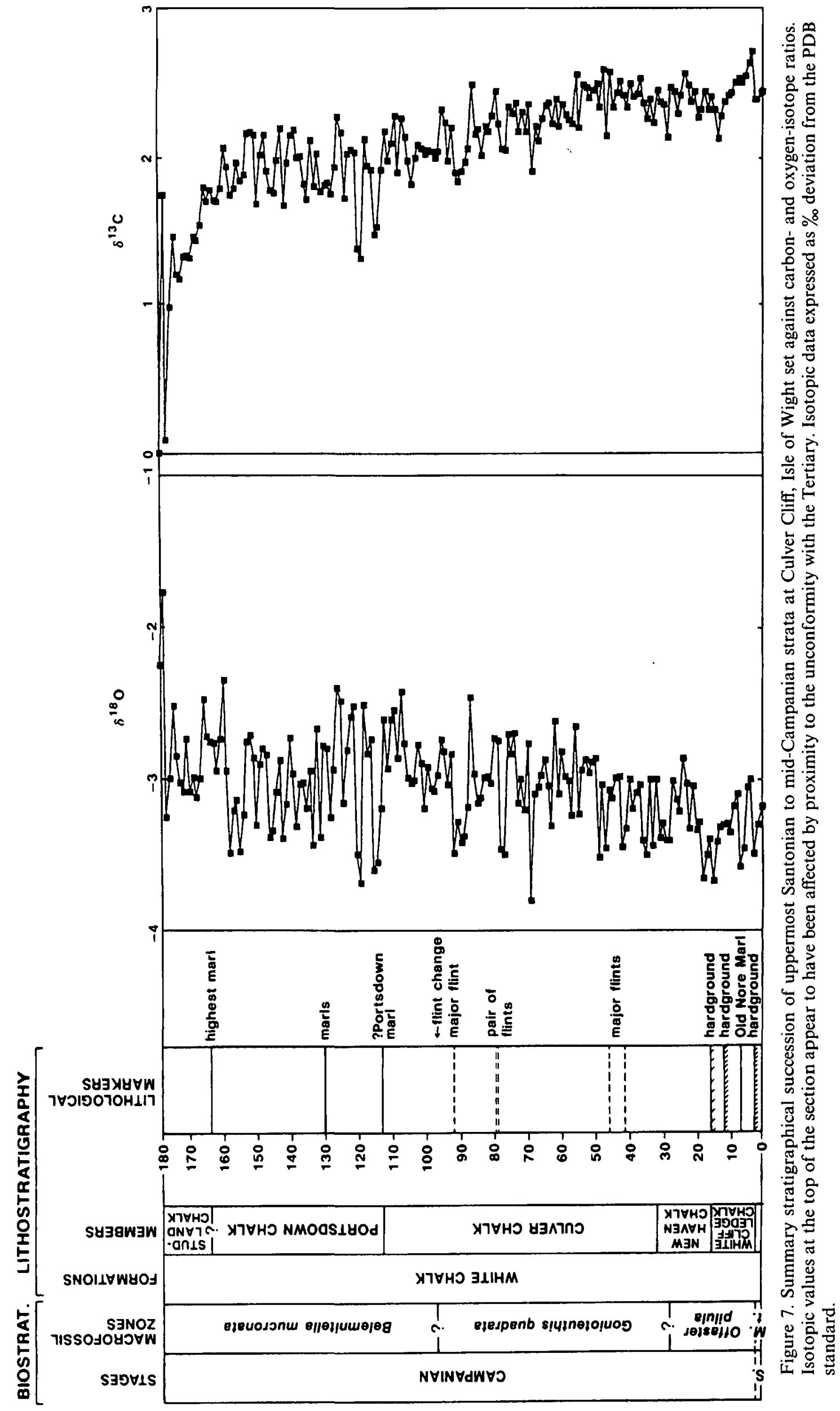




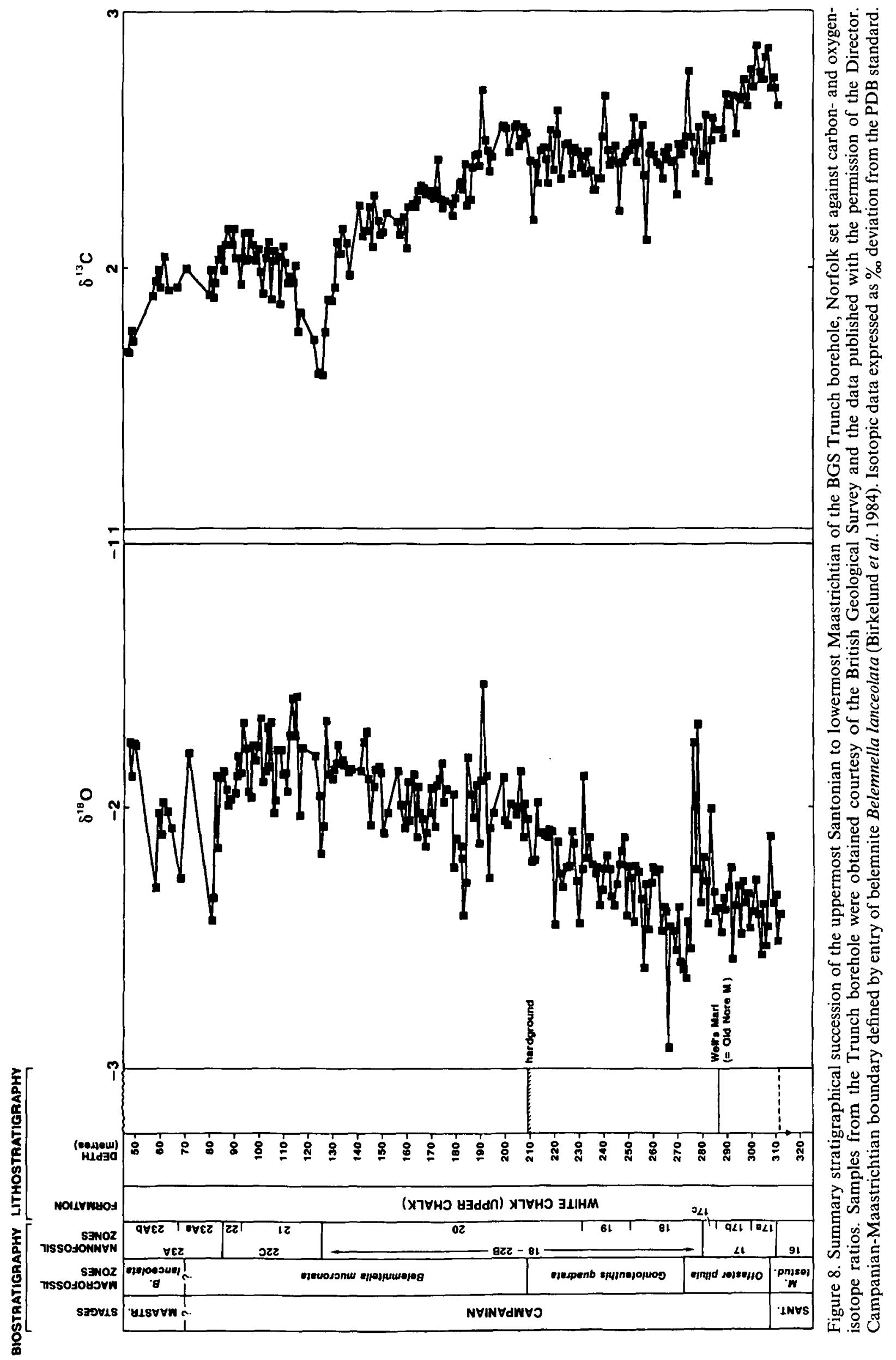




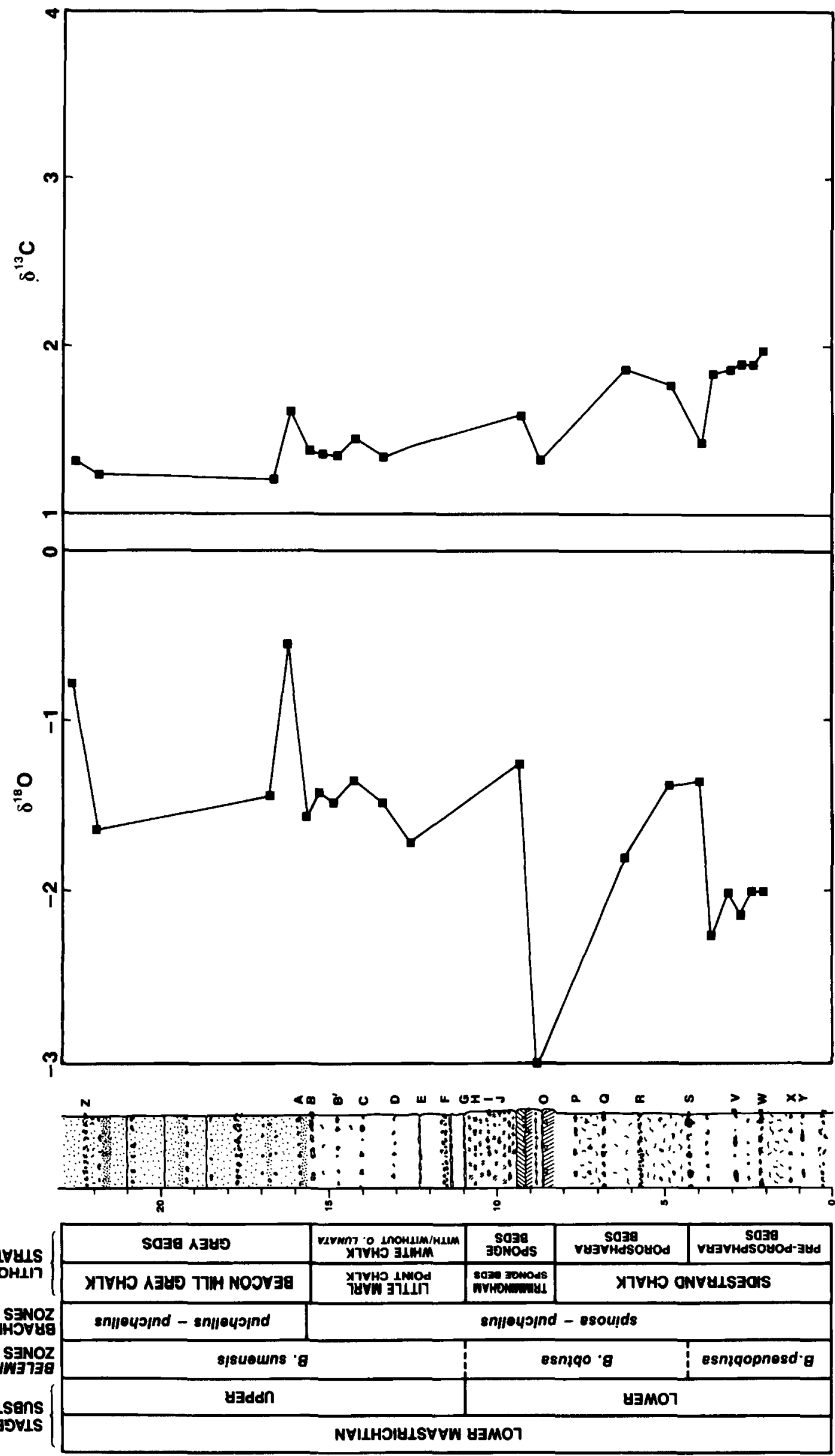

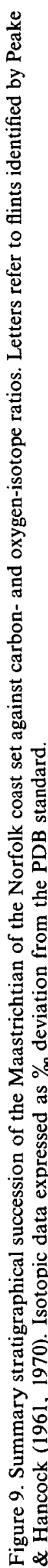


Campanian part of the section (Fig. 6;14 in Appendix), commencing at the level of Whitaker's 3inch Flint (= Rough Brow Flint of Mortimore, 1986). The sequence dips at about $15^{\circ}$ to the west.

The top of the Broadstairs Member (= Seaford Member of Mortimore, 1986) contains weakly indurated limonite-stained nodules and grey-contrasting burrows, equivalent to the level of Barrois' Sponge bed on the Kent coast. The overlying Newhaven Member is characterized by numerous flaser marls, and the conspicuous Old Nore Marl, which is represented in the Trunch borehole and a correlative bed in northwest Germany. Above the highest of the flaser marls (Castle Hill Marls), the basal part of the soft Culver Chalk contains well-defined beds of flint nodules. The carbon- and oxygen-isotope stratigraphy of this section is shown in Figure 6.

\section{3.d. Culver Cliff, Isle of Wight (Santonian-Campanian)}

Coniacian to mid-Campanian chalk is well exposed in the steeply dipping $\left(50-70^{\circ}\right)$ northern limb of the Sandown Anticline at Culver Cliff (SZ 640856) in the eastern Isle of Wight (Fig. 1). The locality was briefly described and zoned by the use of macrofossils by Rowe (1908), and Brydone (1914) published observations on the Offaster pilula Zone. White (1921) provided a general account of the section. The virtually continuous exposure of a considerable thickness of chalk has attracted studies on the planktonic foraminifers (Barr, 1962) and dinoflagellates (Clarke \& Verdier, 1967) but both papers lack detailed stratigraphy.

Mortimore (1983, 1987) published summary logs of the Campanian Chalk at Culver Cliff showing selected marl bands and flints. We are unable to identify many of these with certainty in the field, or to validate his extrapolated correlations from Sussex and south Hampshire to Culver Cliff. The detailed lithological log given here (Fig. 15 in Appendix) is based on observations by A.S.G. over the period 1985-1991.

At Culver Cliff, the uppermost Santonian and lowest Campanian Chalk is represented by the virtually flintless and strongly condensed Whitecliff Ledge Member of Gale, Wood \& Bromley (1987) which contains hardgrounds, nodular chalks and beds of granular phosphorite, and is a thin representative of part of the Newhaven Chalk (Mortimore, 1983). The Culver Member contains fewer marl seams and numerous beds of flint nodules. Above, the Portsdown Member of mid-Campanian age contains many thin marls and several horizons rich in inoceramid bivalve debris, and is abruptly terminated by the unconformity underlying the Palaeocene Reading Beds. The carbonand oxygen-isotope stratigraphy of this section is shown in Figure 7.

\section{3.e. BGS Trunch Borehole, Norfolk}

(Santonian-Maastrichtian)

In 1975, the IGS (now BGS) sank a cored borehole through the chalk at Trunch (Fig. 1) in northeast Norfolk (TG 293345) which proved a total thickness of $468 \mathrm{~m}$ of Cenomanian to lower Maastrichtian Chalk and provides the only entire succession of the Campanian available in England (Gallois \& Morter, 1976; Arthurton et al. in press). McArthur et al. (1993) give some carbon- and oxygen-isotopic data for this core in the context of their investigation into strontium-isotope stratigraphy.

Stratigraphy of the BGS Trunch borehole is based on lithological marker-beds, macrofossil zones (Arthurton et al. in press) and nannofossil zones (Burnett, 1989). The Santonian-Maastrichtian interval comprises soft to firm white nannofossil chalk, including variable amounts of biclastic calcite debris, notably inoceramid prisms, oysters and echinoderm plates. Stylolitic marls are present in the upper Santonian-lower Campanian Chalks, and beds of nodular flint occur at intervals of approximately one metre through much of the succession. A distinctive 6cm-thick green-grey marl at $283.68 \mathrm{~m}$ (Wells Marl) correlates with the Old Nore Marl of southern England (e.g. Seaford Head; see Fig. 14 in Appendix) and the M1 marl of Lagerdorf in northwest Germany (Ernst, 1963; Schönfeld, Sirocko \& Jørgensen, 1991). A major mineralized hardground, with a phosphatized surface, is present at $209 \mathrm{~m}$, and probably corresponds with the A13 hardground in the upper Gonioteuthis quadrata Zone at Downend in south Hampshire (Gale, 1980). The carbon- and oxygen-isotope stratigraphy of this core is shown in Figure 8.

\section{3.f. Norfolk Coast (Maastrichtian)}

In England Maastrichtian Chalk outcrops only as glacially transported masses on the coast of northeast Norfolk, close to Sidestrand and Trimingham, southeast of Cromer (Fig. 1). Individual masses are extensively folded and repeatedly thrust, and the higher parts of the succession are accessible only on exceptionally low spring tides when sand cover has been stripped by wave action. The basic succession was outlined by Brydone (1906, 1908, 1938), and Peake \& Hancock (1961) provided a detailed log of part of the succession and a map of the eastern part of the outcrop. They subsequently (1970) gave further details of the higher part of the section and demonstrated a small overlap in their original log. Johansen \& Surlyk (1990) described the distribution of brachiopods, and gave formal member status names to successive lithological units. Schulz (1979) identified belemnite zonal boundaries in the Maastrichtian Chalk.

The earliest Maastrichtian Belemnella lanceolata 
Zone is represented only by the 3-m-thick isolated Overstrand Hotel Upper Mass (Schulz, 1979), whose relationship with the higher part of the succession is not known. It was not sampled.

The lithological succession given in Figure 9 is based largely on Peake \& Hancock $(1961,1970)$ with additional information from the notes of A. A. Morter and C. J. Wood. The Sidestrand Chalk Member (base not seen) comprises some $10 \mathrm{~m}$ of soft, fine white nannofossil chalk containing beds of distinctive flints and dark-contrasting Thalassinoides and Zoophycos burrows. The Trimingham Sponge Beds contain hardgrounds, nodular chalks and layers of glauconitecoated pebbles. The Little Marl Point Chalk is soft, with beds of nodular flint and marls, and the upper part contains numerous oysters. The Beacon Hill Grey Chalk includes several beds of fawn-coloured calcarenite. The carbon- and oxygen-isotope stratigraphy of this section is also shown in Figure 9.

\section{The stratigraphy of the Italian Scaglia}

The Scaglia Bianca and Scaglia Rossa constitute a series of pelagic limestones, variably clay-rich, that is widespread across the Marchean-Umbrian Apennines of central Italy with equivalents elsewhere in the Alpine-Mediterranean region (Bernoulli, 1972; Bernoulli \& Jenkyns, 1974). Abundant planktonic microfossils, typically foraminifera, have allowed the erection of a detailed biostratigraphy (Premoli-Silva, 1977), as have calcareous nannofossils (Monechi, 1981) and magnetostratigraphy (Lowrie, Channell \& Alvarez, 1980). By far the most intensively investigated section is that exposed near Gubbio, north of Perugia.

\section{4.a. Bottaccione Gorge, Gubbio (Albian-Maastrichtian)}

The section through the Scaglia exposed in the Bottaccione Gorge (Arthur \& Fischer, 1977; Cresta, Monechi \& Parisi, 1989) commences with a lower unit of light grey to light green limestones with bands of black chert (Scaglia Bianca) of late Albian to early Turonian age (Fig. 10). In the upper part of the Scaglia Bianca there is a distinctive $1-\mathrm{m}$-thick level of interbedded black laminated shales and grey radiolarian sands; this is known as the Livello Bonarelli and is dated as latest Cenomanian (Arthur \& PremoliSilva, 1982). Organic-carbon values in these shales, as sampled in various localities around Gubbio, are extraordinarily high, ranging up to $30 \%$ TOC (Farrimond et al. 1990). Some five to eight metres above this carbon-rich horizon, the colour of the sediment, both limestone and chert, changes to pink and the series contains conspicuous clay-rich interbeds; this is the Scaglia Rossa and it extends from the lower Turonian into the Eocene. Both the Scaglia Bianca and Scaglia Rossa are dominantly composed of solution-welded calcareous nannofossils with for- aminifers, chiefly planktonic, accompanied by rare benthonic examples. The carbon- and oxygen-isotope stratigraphy of this section is shown in Figure 10.

\section{Diagenesis versus palaeoceanography}

Previous work has shown that, in terms of chemostratigraphy, analysis of bulk carbonate is useful in that the influence of any 'vital effects' (non-equilibrium fractionation) on isotopic ratios is dampened as the individual signals of many species of nannoand microfossil are effectively integrated (Scholle \& Arthur, 1980). This will remain true as long as the volumetric ratios of differing forms remain relatively constant through time; this would seem to be a reasonable supposition for the Chalk as long as winnowed layers are avoided. The same averaging effect is presumably true for the crystal-face isotopic variability recently documented for calcium carbonate by Dickson (1991). Detailed studies on individual faunal elements such as the calcitic prisms of inoceramids, although undertaken by some workers and used to estimate palaeotemperatures, have proven more problematic. Differences in chemical composition of such skeletal calcite, perhaps related to crystal shape and diagenetic overgrowths, are reflected in pronounced variance in $\delta^{18} \mathrm{O}$ and $\delta^{13} \mathrm{C}$ in samples from the same formation (Pirrie \& Marshall, 1990; Burdett, Arthur \& Lohmann, 1990), a phenomenon recognized by Stevens \& Clayton (1971) and also confirmed in this study. Similar, although less extreme effects have been encountered when the calcitic rostra of belemnites are analysed. Investigations of individual foraminiferal species have, however, been more successful (Douglas \& Savin, 1975; Boersma \& Shackleton, 1981; Corfield, Hall \& Brasier, 1990; Jeans et al. 1991), although the ratio of diagenetic cement to original shell can be uncomfortably large and difficult to quantify.

In order to evaluate the possible influence of diagenesis, a number of samples from the sections studied have been analysed in some detail. The oxygenand carbon-isotope composition from five samples from successive levels immediately above the Plenus Marls in the Melbourn rock at Dover (CenomanianTuronian boundary) show some scatter and clear mixing lines, implying introduction of variable quantities of an isotopically homogeneous cement of more negative composition. For any one sample, $\delta^{13} \mathrm{C}$ values typically vary by up to $0.3 \%$ and $\delta^{18} \mathrm{O}$ by up to $0.5 \%$. Higher in the Turonian, samples show less scatter in the carbon isotopes but similar ranges for $\delta^{18} \mathrm{O}$. Specimens of the Coniacian-Santonian Broadstairs Chalk show even less scatter, suggesting minimal diagenesis. Stereoscan electron micrographs of a range of samples show only a modest amount of cement, in agreement with previous studies (Scholle, 1974; Hancock, 1975), implying very limited post-deposi- 


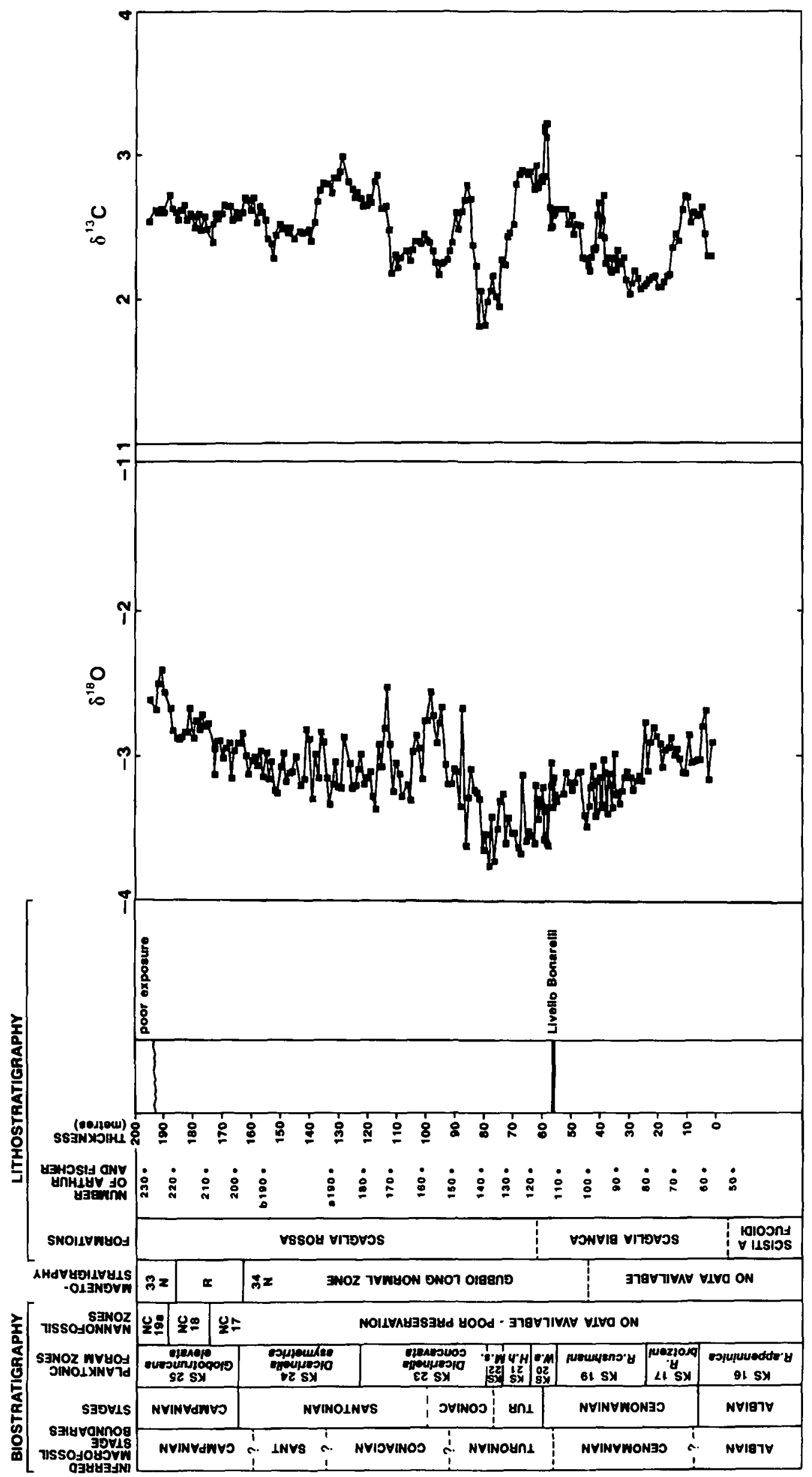

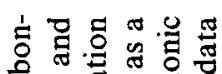

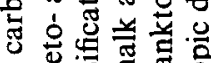

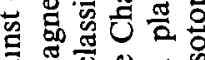

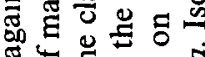

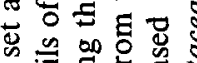
2) 过若

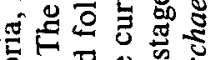

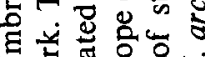

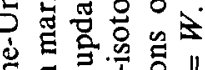

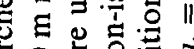

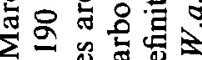

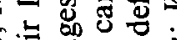

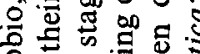

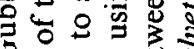
व 究

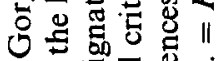

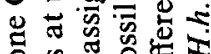
过

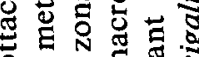

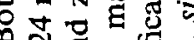

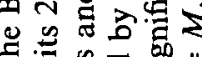

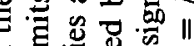
日

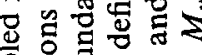
空

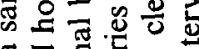

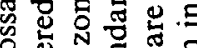

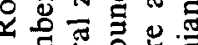
要寻易

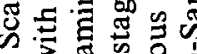

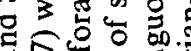

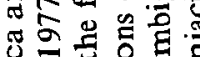
记 0

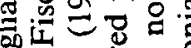

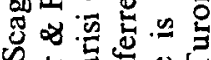

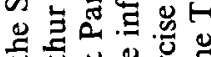

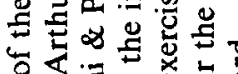
등 द्य

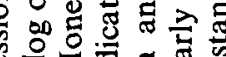
늘 可的象远

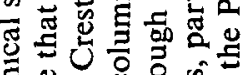

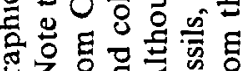

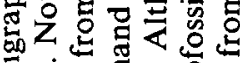

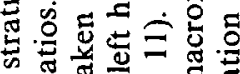

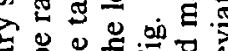

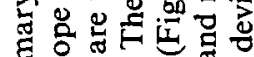
ह के ○

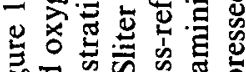

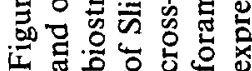


tional alteration. As noted by Scholle \& Halley (1985) the fact that stratigraphically calibrated carbonisotope profiles from a variety of locations thousands of kilometres apart show identical structure and similar absolute values suggest that, even if primary porosity is lost to cement, that precipitate is locally derived.

The oxygen-isotope record is always potentially more suspect as the ratio of oxygen in pore waters to oxygen in initially porous carbonate sediment is high, unlike the situation with carbon. There is thus potential for considerable diagenetic change. Additionally, burial diagenesis at elevated temperature and meteoric-water cementation can diagenetically add isotopically light cement. Effects such as these, borne out by the intra-sample variability described above, have been suggested as significant in the diagenetic history of some European chalks (Scholle, 1974,1977 ) but usually go hand in hand with an obvious decrease in porosity and increase in lithification. Thus the statement of Hudson (1977) that 'any nanno-plankton ooze still in the diagenetic grade denoted by the term "chalk" probably retains its original carbon isotopic composition, and its oxygen isotopic composition will have changed less than that of most fully lithified limestones' is pertinent.

The degree of lithification in the chalks examined in this study is minor; certainly in the ConiacianSantonian-Lower Campanian sections in East Kent (Broadstairs Chalk) the sediment is little more than a firm ooze, although in the Cenomanian-Turonian sections near Dover, where hardgrounds and intraformational nodules abound, lithification is more pronounced. However, the degree of diagenesis does vary from section to section as study of the oxygenisotope ratios of the same stratigraphic intervals at different localities reveals (e.g. Figs 4, 6, 7, 8). Hence, careful choice of section is necessary to produce data carrying the most pristine signal.

The focus on particular intervals a few metres thick (such as Cenomanian-Turonian boundary sections, including the Plenus Marls) for isotopic analysis can lead to problems of correlation, using isotopes alone, if there are local diagenetic overprints; organic and clay-rich sequences can show considerable local variability as the studies of Thierstein \& Roth (1991) on Cretaceous deep-sea sediments have demonstrated. A better understanding of the tenor and scale of diagenesis is obtained when long stratigraphic sequences are analysed; indeed overall correlation between British Chalk sections and the Scaglia Rossa and Scaglia Bianca at Gubbio is also possible, strikingly so with the carbon-isotope profiles (Fig. 11) and to a degree with the oxygen isotopes, even though the absolute values of the latter are on average about $0.5 \%$ lighter in the Italian section (Fig. 10). In summary, we believe that analyses of bulk chalk samples provide an accurate monitor of the changing isotopic chemistry of the Chalk Sea and that the more lithified Italian pelagic limestones still display real trends in the evolution of both carbon- and oxygenisotope ratios in Tethyan ocean waters.

\section{The carbon-isotope profile}

A composite smoothed carbon-isotope profile derived from chalk sections in east Kent, with similarly treated Gubbio data for comparison, is presented in Figure 11. The most obvious feature of the Chalk curve, which in general resembles that published by Scholle \& Arthur (1980), is the pronounced 'heavy' event or positive excursion centred around the Cenomanian-Turonian boundary; moreover, the length of the profile allows one to put this feature in context. Values of $\delta^{13} \mathrm{C}$ show little variation in the basal Cenomanian then dip slightly before rising to a distinct peak in the mid-Cenomanian. This midCenomanian feature has already been noted by Gale

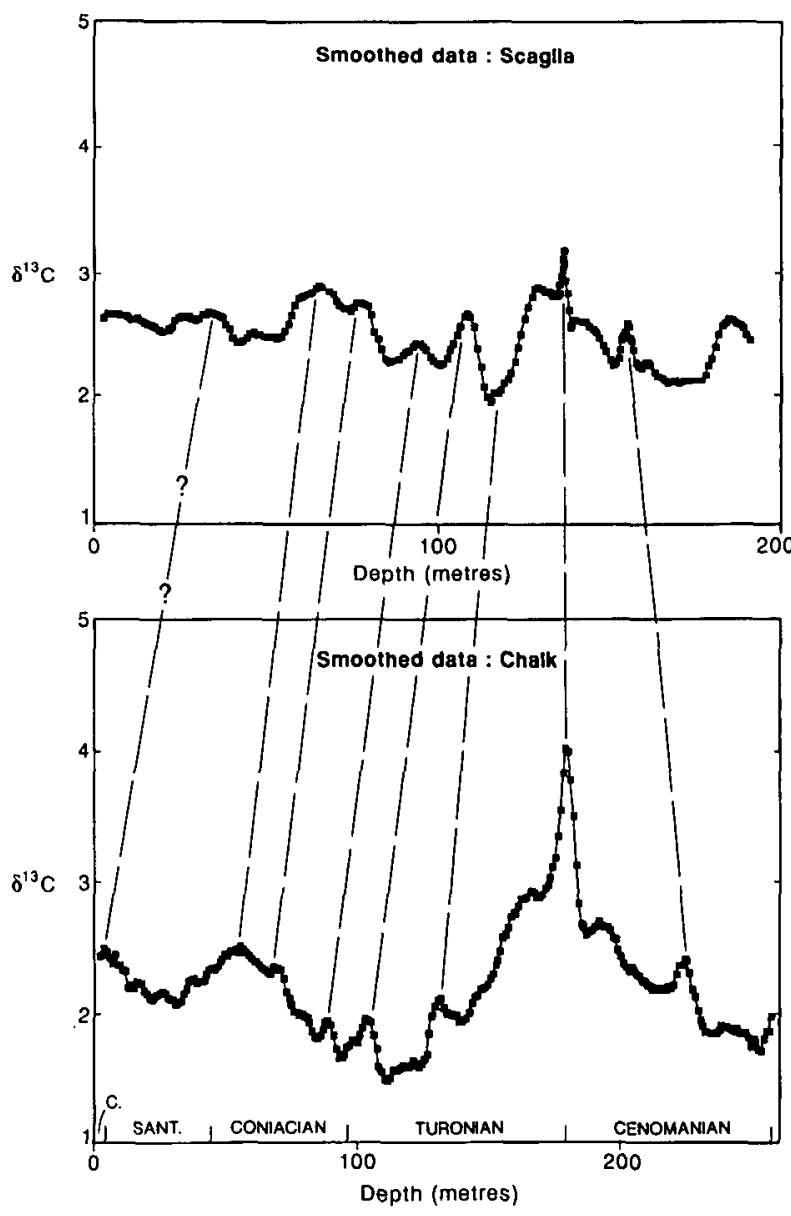

Figure 11. Composite $\delta^{13} \mathrm{C}$ curve for the Chalk of East Kent compared with that of the Scaglia from the Bottaccione Gorge, Gubbio, with proposed tie-lines. Both curves have been smoothed using a five-point moving average. Note the remarkable correspondence in the structure of both curves, even though absolute values differ somewhat. Tie-lines indicate the relatively condensed nature of the CenomanianTuronian boundary section in Gubbio. Stages are based on macrofossils from the English Chalk. Isotopic data expressed as \% deviation from the PDB standard. 
(1989), occurs also in the Gubbio section, and is clearly real.

Higher in the section values begin to climb then fall back until they jump dramatically to reach a high greater than $4 \%$ ( $4.52 \%$ in the primary data; Fig. 3$)$ in the very latest Cenomanian; thence there is a steep decline, punctuated by peaks of minor dimension in the mid- and latest Turonian. A small positive disturbance in the early Coniacian is followed by a broad peak in the latter part of the stage with maximum values a little over $2.5 \%$; next comes a trough before a subsequent rise into the Campanian. All these features, albeit with somewhat differing magnitude and absolute values, are similarly recognizable in the Gubbio section (Figs 10,11); a notable difference, however, with the Italian section is the dampening of the excursion in the immediate stratigraphical vicinity of the Livello Bonarelli (highest Cenomanian), a phenomenon readily attributed to the impact of early diagenetic degradation of organic matter in the black shale and local precipitation of isotopically light cement (Schlanger et al. 1987; cf. Irwin, Curtis \& Coleman, 1977). Furthermore, the absence of carbonate in the Bonarelli level itself precludes the acquisition of relevant isotopic data for this interval.

Given that the Cenomanian-Turonian positive excursion has been successfully interpreted in terms of abnormally high rates of organic-carbon burial in diverse parts of the globe (e.g. Arthur, Schlanger \& Jenkyns, 1987) it is useful to view other structures in the curve in similar terms. Starting first with the small mid-Cenomanian peak it is apparent at once that there is no obvious and widespread black-shale record from the oceans or from outcrop. Indeed the midCenomanian in many North and South Atlantic deepsea drilling sites is represented by a hiatus (de Graciansky et al. 1986). Rare mid-Cenomanian organic-rich facies do occur, however, in some North Atlantic holes; Sites 367 in the Cape Verde Basin; Site 398 in the apron of Vigo Seamount, Site 386 on Bermuda Rise are cases in point (Cool, 1982; Arthur \& Dean, 1986; Summerhayes, 1987) and lack of stratigraphical refinement means that some may have been misassigned. A thin laminated organic-rich layer of early mid-Cenomanian age also occurs in the Vocontian Trough, southern France (ASG, personal observation), but in general the overall record is not impressive. If we follow the logic of interpreting all regional positive carbon-isotope shifts as indicating movement of carbon from the 'oxidized' to the 'reduced' reservoir it follows that a more impressive record exists somewhere or formerly existed. Given the widespread hiatus across the Atlantic and neighbouring margins and shelves over this interval, it is certainly possible that an originally more widespread carbonaceous record has been removed by later erosion. Such erosion and accompanying oxidation would have returned isotopically light carbon to the ocean.

However, even substantial positive carbon-isotope excursions are not always accompanied by an obvious marine black-shale record as shown by the example in the Palaeocene (Shackleton, 1986). This interval is characterized by a $2.5 \%$ positive shift recognizable in all major oceans but is apparently not accompanied by a well-developed, well-preserved or well-documented black-shale record; a rare exception would be Site 387 on the western Bermuda Rise in the deep North Atlantic (Tucholke \& Vogt, 1979). Storage of terrestrial organic carbon may have to be considered in this case (cf. Shackleton, 1987).

A positive carbon-isotope shift could also be produced by changing the overall isotopic composition of organic carbon entombed as marine or terrestrial sediment to more negative values while keeping the burial rate constant (Jenkyns, 1988). Equally, changing the interplay between productivity, with accelerated extraction rates of ${ }^{12} \mathrm{C}$ in near-surface waters, and recycling of nutrients, which usually involves upwelling and introduction of ${ }^{12} \mathrm{C}$-rich waters, could affect the carbon-isotope composition of waters in the photic zone and skeletal calcite secreted therein (Berger \& Vincent, 1986). However, such effects would be essentially local rather than regional in character. Possibly relevant to this discussion is the observation that, from the higher part of the Turonian upwards, the $\delta^{13} \mathrm{C}$ profile of the Gubbio section is some $0.5 \%$ heavier than the less diagenetically altered Chalk, implying that ${ }^{12} \mathrm{C}$ depletion in Late Cretaceous marine waters was more significant around the Tethyan continental margin than in north European epicontinental seas; clearly some partitioning of palaeo-water-masses is being registered. Did upwelling/nutrient input and plankton productivity play different roles in the two areas or were the more important sinks for organic carbon in the deeper waters of the Tethyan and Atlantic oceans? Stratigraphical evidence is certainly consistent with the latter alternative.

The Cenomanian-Turonian boundary curve is similar to many already published (e.g. Scholle \& Arthur, 1980; Schlanger et al. 1987; Jarvis et al. 1988; Corfield et al. 1991). We also present, in Figure 5, a detail from this interval expressed in the stratigraphically expanded and relatively complete section at Eastbourne; this indicates a $0.5 \%$ fall after the initial steep rise, followed by a series of minor peaks and troughs before peaking again at the Cenomanian-Turonian boundary (Gale et al. 1993). The long isotopic profile presented in Figure 3 clearly shows, however, that this peak itself sits on a broad shoulder, suggesting that regional organic-carbon extraction began early in the late Cenomanian before culminating in the event itself, a point emphasized by Arthur, Schlanger \& Jenkyns (1987). Data from 
northern Europe have been taken to suggest that, although the isotopic excursion may be synchronous, black-shale deposition was not (Hilbrecht, Arthur \& Schlanger, 1986; Hart \& Leary, 1989).

Decay of the Cenomanian-Turonian boundary peak appears rapid but the curve is punctuated by a step before being characterized by a subsidiary peak in the mid-Turonian. This mid-Turonian disturbance, present in the Gubbio section (Fig. 10), is also recognizable in some carbon-isotope profiles from the Western Interior Seaway of North America (Pratt et al. 1993) and appears to be a regional phenomenon.

In terms of the Atlantic record of mid-Turonian black shales, such certainly exists in parts of the eastern North Atlantic and the South Atlantic north of the Walvis Ridge-Rio Grande Rise (de Graciansky et al. 1986). On the São Paulo Plateau (DSDP Site 356 ), for example, black shales of early to midTuronian age are recorded with TOCs up to $15 \%$ (Herbin, Magniez-Jannin \& Müller, 1986). Honigstein et al. (1989) have specifically documented a 'midTuronian anoxic event' from the Cretaceous of Israel, and in Morocco carbon-rich sedimentation locally took place at the same time (Einsele \& Wiedmann, 1982; Thurow, Kuhnt \& Wiedmann, 1982). A similar stratigraphic pattern may be recognizable in Tunisia although the facies suggest that organic-carbon values decline above the Cenomanian-Turonian boundary (Robaszynski et al. 1990). These outcrops in North Africa exemplify a common problem, also manifest in the South Atlantic, namely the difficulty of isolating the episode from a continuation of that at the Cenomanian-Turonian boundary without detailed organic-carbon profiles.

A small positive disturbance in the high Turonian is also recognizable, followed by a smaller excursion low in the Coniacian. Current levels of biostratigraphic resolution in organic-carbon profiles from the Atlantic do not permit recognition of these intervals as in any way unusual. The next major, stratigraphically higher feature on the curve is the broad late Coniacian excursion, of remarkably similar demeanour in both the Chalk and Scaglia isotopic profiles. This isotopic feature, also recognizable in the Cretaceous of the Western Interior (Pratt et al. 1993) is coincident with deposition of carbon-rich shales in the Atlantic, Caribbean and South American regions. Upper Coniacian black shales were noted by Ryan \& Cita (1977) from a number of Atlantic DSDP sites and, on the basis of these and other occurrences, an oceanic anoxic event of Coniacian-Santonian age was postulated by Jenkyns (1980). Further manifestations of this episode are now documented from the North and South Atlantic (de Graciansky et al. 1982; Herbin, Magniez-Jannin \& Müller, 1986). In the Venezuelan Andes, Tribovillard et al. (1991) have noted that the La Luna Formation, a carbon-rich unit, extends upwards from the Cenomanian and contains some intervals of relatively high TOC in the ConiacianSantonian interval. In the Gulf Coast of the USA the upper Coniacian (horizon with Volviceramus involutus) part of the Austin Chalk is laminated and organic-rich (ASG, personal observations). In the Western Interior, the equivalent horizon is represented by the Lower Marl (Shale) of the Smoky Hill Member of the Niobrara Chalk and is notably carbonaceous with TOCs rising to more than 5\% (Pratt et al. 1993).

A short-lived but widely developed positive excursion of nearly $0.5 \%$ is registered in uppermost Santonian-lowermost Campanian sediments from east Kent, and is also seen in data from Seaford (Fig. 6) and Trunch (Fig. 8). The same feature is evident from the data of Schönfeld, Sirocko \& Jørgensen (1991) from Lagerdorf, northwest Germany, and is also registered in the Western Interior (Pratt et al. 1993). Above the decay level of this excursion, values of $\delta^{13} \mathrm{C}$ remain relatively constant, albeit with some minor peaks and troughs, through the early Campanian, before commencing a gradual fall in the latter part of the stage. The data from Culver confirm this trend.

The negative excursion seen in the higher part of the Campanian from the Trunch borehole is also seen in Norfolk data presented by Scholle \& Arthur (1980) and its significance is not entirely clear. Given that there is some correlation with the oxygen-isotope ratios (Fig. 8), it could be interpreted as a diagenetic artifact but it more probably is real; isotopic values from the top of the Culver section (Fig. 7), although affected by the proximity of the unconformity with the Tertiary, show a similar trend. The limited analyses of Campanian chalks from north Germany are, however, ambiguous in this regard (Schönfeld, Sirocko \& Jørgensen, 1991). The general decrease in $\delta^{13} \mathrm{C}$ continues through the early Maastrichtian (data from northeast Norfolk; Fig. 9) to values a little above $1 \%$.

\section{The carbon-isotope profile as a correlative tool}

The remarkable similarity between the $\delta^{13} \mathrm{C}$ curves for the Italian Scaglia and the English Chalk (Fig. 11) underscores the potential of this sort of isotope stratigraphy as a correlative tool, as originally suggested by Scholle \& Arthur (1980). In the case of the two sections illustrated here it is immediately apparent that there are discrepancies in the positions of the stage boundaries based on macrofossils versus those defined on microfossils. Such mismatches are particularly acute for the Turonian, Coniacian and Santonian stages. A notional macrofossil stratigraphy for the Scaglia, using the tie-lines in Figure 11 to mark the stage divisions, is given in Figure 10.

On a finer scale, as recently illustrated by Gale et al. (1993), the $\delta^{13} \mathrm{C}$ Cenomanian-Turonian boundary curve from Eastbourne (Fig. 5) can be matched in every detail with that from Pueblo, Colorado, USA, 
and in both cases faunal and floral datums occupy the same relative positions and have a consistent relationship with the isotopic profile. Thus the contention of Bralower (1988) that there is apparent diachroneity between nannofossil boundaries and the isotopic excursion in the Western Interior of the United States and a larger offset still when compared to northern Europe, can be resolved by understanding the complex and multi-peaked nature of the isotopic spike. Apparently the carbon-isotope curve, wherever possessed of characteristic shape and form, has correlation potential of global scale.

\section{The carbon-isotope profile as a proxy for sea level}

The general correlation between the carbon-isotope profile and various putative sea-level curves has been commented upon by several authors (Scholle \& Arthur, 1980; Arthur, Schlanger \& Jenkyns, 1987; Weissert \& Lini, 1991). As has long been recognized, stratigraphical evidence from a variety of sources (Suess, 1888; Hancock \& Kauffman, 1979; Weimer, 1984; Haq, Hardenbol \& Vail, 1988; Hancock, 1989) suggests that relative sea-level rose throughout the Cenomanian to peak in the earliest Turonian after which there was a regressive phase, an evolutionary pattern that closely matches the carbon-isotope curve (Fig. 11). Small peaks in the Cenomanian portion of the carbon-isotope curve correspond with onlap surfaces in the Anglo-Paris Basin (Robaszynski et al. 1992). From the Coniacian onwards the isotope curve corresponds more closely with the proposed sea-level changes in North America than in Europe. The Cretaceous sea-level curve for the Western Interior generated by Weimer (1984) shows this relationship particularly clearly, but similar patterns, including a late Campanian fall, are seen in the curves for central West Africa (Seiglie \& Baker, 1984) and Israel (Flexer et al. 1986).

Most organic carbon in the marine realm is synthesized and deposited in shelf and marginal regions where upwelling and riverine input of nutrients is locally important, transit depths to the sea floor relatively modest and sedimentary rates relatively greater than in the pelagic realm (see e.g. Pelet, 1987). Thus, it may be argued that transgression, rather than eustatic sea-level rise per se, by increasing the volume of shelf seas, could increase the amount of carbon produced and buried and hence raise the ${ }^{13} \mathrm{C} /{ }^{12} \mathrm{C}$ ratio of the world ocean. This simple approach does, however, beg a number of questions. For example, the geographic distribution of carbon-rich beds of Cenomanian-Turonian age is clearly not limited only to shelf and continental-margin regions, even though these areas contain the most impressive (or perhaps most accessible) record (Schlanger et al. 1987). Those that occur in the Pacific Basin, however, formed under the Equator which is today, and presumably was in
Cenomanian-Turonian time, a locus of upwelling, relatively high organic productivity and mid-water oxygen depletion. The hypothesis that the distribution of Cenomanian-Turonian carbon-rich shales reflects an upwelling/productivity signal, albeit of global dimensions, is certainly defensible.

If marine productivity is the controlling factor on organic richness in sediments, as some authors have argued (e.g. Pedersen \& Calvert, 1990) it follows that nutrient availability during the CenomanianTuronian boundary interval was sufficient to permit anomalously high rates of organic-carbon production and burial in shelf seas swollen by the Late Cretaceous transgression. Nonetheless, as deposition of organic facies would have withdrawn nutrients such as phosphate and nitrate from the marine system, it is likely that any widespread black-shale episode (oceanic anoxic event) would have been automatically and rapidly self-limiting. Here it is important to distinguish between shelf-sea area and the rate of transgression. If flooding of a landmass proceeded rapidly enough to flush nutrients from deeply weathered soils directly into the sea or perhaps triggered accelerated marine evaporation from warm shelf seas followed by increased precipitation on, and fluvial input of nutrients from, continental areas, then high productivity and carbon burial could have been sustainable for some time. Thus, an oceanic anoxic event and accompanying positive isotope excursion could correlate with the time of most rapid rate of marine inundation, rather than with the time of peak transgression or maximum flooding.

Stratigraphic evidence suggests that in Europe and the United States maximum flooding was achieved in the early to mid-Turonian (Hancock \& Kauffman, 1979; Haq, Hardenbol \& Vail, 1988; Hancock, 1989; Jenkyns, 1991) clearly post-dating the anoxic event. Thus, the carbon-isotope profile could contain information both on continental area coupled with information on rates of flooding. Within certain limits, correlation between the curve and the sea/land area ratio may be very good, although extreme isotopic events may require an additional explanation. Regression, were it to be accompanied by erosion, seaward transport and oxidation of carbon-rich deposits, would clearly be registered by a pronounced dip in the carbon-isotope profile.

Clearly, seaward transport of nutrients and/or anoxic water from shelves would be required to explain the development of Pacific and similar openocean black shales, if they are considered as related phenomena. Occurrences such as these render attractive the model of Arthur, Schlanger \& Jenkyns (1987) which suggests a relationship between shelf-sea area and upwelling of deep oceanic water masses. Notably the most marine carbon-rich CenomanianTuronian record in Europe generally occurs in distal pelagic sediments (such as the Livello Bonarelli) 
deposited in considerable water depth, rather than in shallower-water chalks where the organic matter also differs by being relatively richer in higher-plant debris (Jenkyns, 1985; Jeans et al. 1991). The lack of a pronounced $\delta^{13} \mathrm{C}$ gradient in the English Chalk sea during the Cenomanian-Turonian boundary interval also suggests negligible increase in productivity (Corfield, Hall \& Brasier, 1990). Was marine productivity and oxygen depletion more intense offshore? If the Cenomanian-Turonian transgression was causally linked to a global or quasi-global increase in productivity, the challenge is to understand the exact linkage between the two phenomena.

\section{The oxygen-isotope profile}

In converse to workers on Neogene palaeoceanography, geologists studying the Mesozoic have tended to distrust the significance of oxygen-isotope records, assuming that any primary signal would have been grossly modified by diagenesis. However, as noted above, the Chalk itself at the localities sampled here has suffered little diagenesis and the sequences are in general no more altered than DSDP or ODP material of comparable age. The oxygen-isotope profile is illustrated in Figure 4; intra-sample variability of up to $0.5 \%$ in any one chalk sample gives some idea of potential error. Campanian data from Culver and the Trunch borehole are not included in Figure 4 as the absolute values are consistently more negative than those at the same stratigraphic level in East Kent.

The most striking factor in Figure 4 is that there is not a monotonic lightening of oxygen-isotope values with depth but that below the Cenomanian-Turonian boundary values become heavier again. Such a relationship precludes the notion that progressively greater quantities of diagenetically derived, isotopically light cement have been added with increasing burial depth or that progressive recrystallization has taken place; rather it is consistent with the notion that a primary signal is being registered. The Chalk sections analysed here show roughly parallel $\delta^{18} \mathrm{O}$ trends for any given stratigraphic interval, even though absolute values may be different. Furthermore, the fact that a closely comparable isotopic signature, albeit considerably more 'noisy', is visible in the Gubbio sequence from the Italian Apennines (Fig. 10), a sequence that has undergone an entirely separate burial and uplift history, is also persuasive of the primary nature of the signal.

The original oxygen-isotope data of Scholle \& Arthur (1980) from Dover/Folkestone show essentially the same trend, including a pronounced dip across the Cenomanian-Turonian boundary. The significance of this dip warrants further discussion as it occurs close to the level of the Plenus Marls where the sediments are more clayey and organic-carbon- rich, lithological factors which can be associated with relatively negative oxygen-isotope values (Thierstein \& Roth, 1991; Sass, Beïn \& Almogi-Labin, 1991). Most of the extreme negative values are, however, localized in the Melbourn Rock and it could be plausibly suggested that the relatively greater quantity of early diagenetic cement at this level has influenced the oxygen-isotope ratios. As noted above, detailed studies across individual chalk samples from this horizon do reveal a 'mixing line' produced by planktonic carbonate to which variable quantities of isotopically homogeneous cement have been added. However, the amount of variance is small. Hence diagenesis does not seem to be sufficient explanation for the isotopic signature. The detailed profile, sampled every half metre, from Eastbourne (Fig. 5) shows a similar but broader negative excursion; the pronounced dip in the Dover/Folkestone succession is thus most probably a function of the relatively condensed nature of the section and is registering a primary signal.

Intriguingly, the more closely spaced oxygenisotope data of Jarvis et al. (1988) from the Dover section show a small 1\% heavy 'event', which correlates positively with the $\delta^{13} \mathrm{C}$ curve, at the level of the Plenus Marls, although the overall trend is similar to that illustrated here. The significance of this small excursion, which is also registered on our curve from East Kent, albeit with only one sample, is controversial. Jeans et al. (1991), who also record this phenomenon in benthonic foraminifera, suggest it is related to a cooling episode involving significant glaciation; they note the association with boreal faunal elements in the upper part of the Plenus Marls. However, given the correlation with the $\delta^{13} \mathrm{C}$ curve (productivity/carbon-burial index), it may be more simply and less controversially explained as related to upwelling of colder (and nutrient-rich) waters onto the European shelf (Jarvis et al. 1988), or southward invasion of a cooler water mass with a somewhat heavier carbon-isotope composition. The Eastbourne data (Fig. 5) show relatively positive $\delta^{18} \mathrm{O}$ values both at the level of the Plenus Marls and the Meads Marls, suggesting that the latter may also have palaeoceanographic significance.

Recent publications on oxygen-isotope values in the chalk, remarking on the increasingly negative values with depth, have stressed the role of chemical alteration during diagenesis, that is, temperatureinduced isotopic re-equilibration of the chalk-interstitial fluid system (Jørgensen, 1987). Maliva, Dickson \& Raheim (1991), in fact, dismiss the notion of any real secular difference in the oxygen-isotopic composition of primary calcite in chalks from the North Sea; unfortunately, their coverage did not extend significantly below the Cenomanian-Turonian boundary and there is little stratigraphic data in their paper. Schönfeld, Sirocko \& Jørgensen (1991), in their 
study of Upper Cretaceous chalks from northwest Germany, illustrate a similar trend of lightening oxygen isotopes with depth, albeit with somewhat more positive values than those observed in the more diagenetically advanced chalks from the North Sea. They suggest that burial diagenesis has been most important in the upper hundred metres of section, of late Campanian to early Maastrichtian age, where values change most rapidly; their Campanian curve differs little from that of Trunch (Fig. 8). However, other authors (e.g. Renard, 1986; Clauser, 1987), who have documented these trends from other sections in the Tethyan-Atlantic sector, have dismissed diagenesis as being the sole contributor to isotopic variance with age/depth and spotlighted the role of temperature and palaeoceanographic change. The data presented here point strongly to this presumption being correct.

In the simplest case the oxygen-isotope signatures of the lithified German and North Sea chalks could be simply explained by addition of volumetrically similar quantities of diagenetic cement of relatively constant isotopic composition to a primary pelagic sediment carrying an imprint of falling palaeotemperatures. In this case any graph showing $\delta^{18} \mathrm{O}$ plotted against stratigraphical age would show exactly parallel traces but with differing offsets. As there is some departure from this ideal state, and values show considerable scatter, it is apparent that the original sediment was characterized by variable primary porosity and the subsurface environment by different amounts of fluid input and variable pressure-temperature regimes (Scholle, 1977). Nonetheless, the fundamental oxygenisotope signature of all chalks and limestones in the European area may be interpreted as revealing a fingerprint of climatic deterioration during postCenomanian time. The causality of this decline is discussed in section 10 .

\section{The Cenomanian-Turonian boundary event as a climatic threshold}

That the Cenomanian-Turonian boundary event or oceanic anoxic event might have been associated with or influential in global climatic cooling was suggested by Arthur, Dean \& Pratt (1988), although they noted the paucity of supporting oxygen-isotope data. Burial of anomalously large amounts of organic carbon during this event, estimated to have lasted some 0.5 Ma (Arthur \& Premoli-Silva, 1982; Jenkyns, 1985; Arthur, Schlanger \& Jenkyns, 1987) would have resulted in a rise of the $\mathrm{O}_{2} / \mathrm{CO}_{2}$ ratio in the atmosphere by increasing the former at the expense of the latter. Arthur, Dean \& Pratt (1988) suggest that a Cretaceous atmosphere with a $p \mathrm{CO}_{2} 4$ to 18 times higher than present could have been stripped of its $\mathrm{CO}_{2}$ in around 120000 years if the effect of the oceanic reservoir is ignored. Such a change would, of course, qualify as an inverse greenhouse effect.
Such an effect is not unique in the geological record. During the earliest late Miocene, for example, there was regional deposition of carbon-rich diatomites around the Pacific Rim accompanied by a $1 \%$ positive shift in $\delta^{13} \mathrm{C}$ in deep-sea carbonates from the Indian and Pacific oceans (Vincent \& Killingey, 1985; Vincent $\&$ Berger, 1985). This Neogene high-resolution record is of interest because the carbon-isotope excursion was followed by a movement towards heavier oxygenisotope values denoting a falling temperature trend, that is, the carbon-burial event and consequent reduction in the $\mathrm{CO}_{2}$ content of the air conditioned the globe for oceanic and atmospheric cooling. Inspection of the chalk isotopic profiles similarly shows a lag between the onset of the carbon-isotope excursion and the beginning of the heavier oxygenisotope trend interpreted as registering climatic deterioration. The detailed profiles across the Cenomanian-Turonian boundary at Eastbourne (Fig. 5) show this particularly clearly.

Oxygen-isotope data from the English Chalk (Fig. 4), re-expressed as palaeotemperatures using the formula of Anderson \& Arthur (1983), are displayed in Figure 12. Such determinations are essentially 'naive' in that they derive from a mixture of planktonic and benthonic components to which a variable amount of diagenetic cement has been added. However, as demonstrated by Shackleton (1986), pelagic bulk sediments do indicate real palaeotemperature trends and such is considered to be the case here, although the values are presumably overestimates given the presence of a little isotopically light cement. The data show a clear maximum at the Cenomanian-Turonian boundary with temperatures in the high twenties centigrade followed by an irregular decline thereafter.

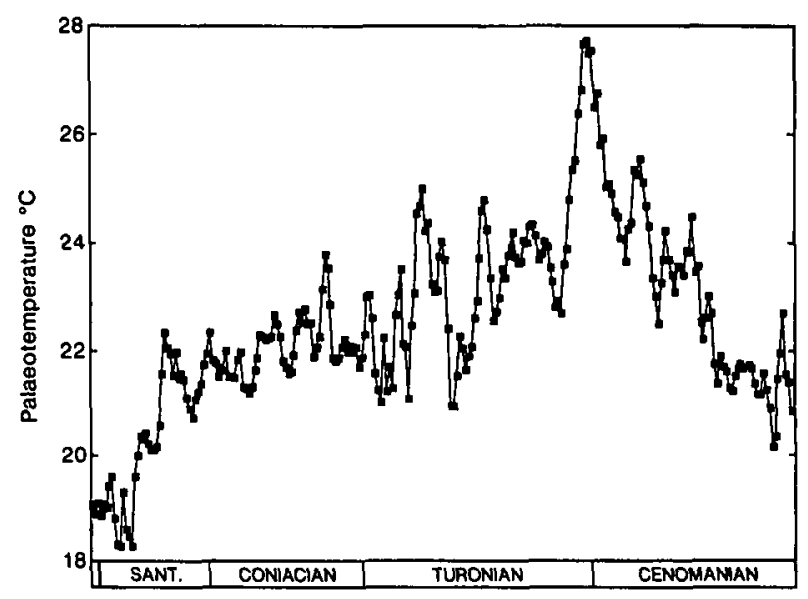

Figure 12. Palaeotemperature curve from the Chalk of East Kent. Palaeotemperatures have been derived from the $\delta^{18} \mathrm{O}$ curve using the formula of Anderson \& Arthur (1983); the results have then been smoothed using a three-point moving average. Given the presence of a variety of components in the Chalk as well as some diagenetic isotopically light cement, the absolute values must be considered approximations, even though the trends are undoubtedly real. Data points from the Glauconitic Marl have been excluded. 
The Gubbio data (calculated from data in Fig. 10) are generally comparable, albeit yielding somewhat higher palaeotemperatures. These are most likely an artifact of burial diagenesis. From comparable oxygen-isotope values at the Cenomanian-Turonian boundary in the two profiles (Figs 4, 10) the curves diverge with that from Gubbio typically being between 0.5 and $1 \%$ lighter; this latter trend is similar to that illustrated by Corfield et al. (1991). This gives the impression of continued warming during the earliest Turonian in the Italian region before the onset of climatic decay; such, however, could be a function of differential alteration of the section above the black shales of the Livello Bonarelli. Multiple analyses of Scaglia Rossa sampled a few metres above the Cenomanian-Turonian boundary show more scatter in their carbon- and oxygen-isotope values than elsewhere in the section, suggesting that the role of diagenesis has been locally important. However, the fact that, at the Cenomanian-Turonian boundary, the $\delta^{18} \mathrm{O}$ values are comparable to those in the Chalk whereas elsewhere, stratigraphically above and below, the Gubbio values are systematically lighter, is puzzling in this regard.

\section{Comparison with other Cretaceous oxygen-isotope data}

The pioneering work of Urey et al. (1951), expanded and amplified by Lowenstam \& Epstein (1954), illustrated the potential use of oxygen-isotope ratios in belemnites, other macrofossils and chalks to determine palaeotemperatures. Their data, derived from samples collected primarily in Europe and the southeastern United States, were taken to suggest a thermal maximum in the Albian followed by a decline before a progressive rise in ocean temperatures from the Cenomanian onwards, climaxing in the Coniacian-Santonian followed by deterioration into the Maastrichtian. A troubling feature of these palaeotemperature curves was the spread of belemnite data points from any one stratigraphical level (e.g. $\delta^{18} \mathrm{O}=0.5$ to $1.2 \%$ for a lower Campanian level from Sweden) and from within any one fossil $\left(\delta^{18} \mathrm{O}=0.3\right.$ to $1.7 \%$ for a Campanian belemnite), the latter interpreted as seasonal temperature variation. The lack of data points around the Cenomanian-Turonian boundary, however, was notable in the Lowenstam \& Epstein compilation and some stratigraphical misassignments skewed the picture in a minor way (Bowen, 1966).

The subsequent work of Spaeth, Hoefs \& Vetter (1971) also showed oxygen-isotope variance typically up to $1.5 \%$ in $\delta^{18} \mathrm{O}$ and $2 \%$ in $\delta^{13} \mathrm{C}$ within single specimens of calcitic belemnite rostra. Detailed geochemical studies by Veizer (1974) on Jurassic and Cretaceous belemnites from Germany suggested that enough post-depositional exchange had taken place between calcitic rostra and surrounding rocks to compromise their use in palaeotemperature analysis. Subsequent work has confirmed the original mineralogy of the rostrum as low-magnesium calcite and shown that most diagenetic effects are concentrated in zones adjacent to the alveolus and the apical line (Saelen, 1989; Saelen \& Karstang, 1989); plausible palaeotemperatures can be obtained if these zones are avoided.

Interestingly the total range of $\delta^{18} \mathrm{O}$ values captured from Cretaceous belemnites from north-west Germany by Spaeth, Hoefs \& Vetter (1971) indicated that highest palaeotemperatures were obtained during Albian-Cenomanian time, but the lack of stratigraphical refinement precluded a more focused analysis, and the absence of determinations from both the Turonian and Coniacian stages was an obstacle to gaining a view of overall isotopic variance through the Late Cretaceous. In an attempt to redress these problems a palaeotemperature curve derived from the Lowenstam/Epstein data was constructed by Savin (1977) using only the heaviest oxygen-isotope values on the assumption that the samples from which they derived were the least altered. This showed a thermal maximum in the Turonian. Savin, however, noted that this approach could screen out records of genuine high temperatures.

Palaeotemperature determinations from belemnites and other macrofossils collected from the Russian Platform and adjacent areas by Naydin, Teys \& Zadorozhnyy (1966) were hamstrung by poor-quality data from the Albian and Cenomanian. Although their palaeotemperature data points showed spectacular spread and particular trends were difficult to defend, the authors commented that neither the Cenomanian minimum nor the Coniacian-Santonian maximum illustrated by Lowenstam and Epstein could be recognized. Indeed the more limited data set assembled by these authors from Crimea (Teys, Chupakhin \& Naydin, 1957) indicated temperature maxima in the late Albian-Cenomanian and late Maastrichtian.

Stevens \& Clayton (1971), in their detailed examination of Cretaceous belemnites from New Zealand, and their compilation of other relevant data, presented a palaeotemperature curve based on the heaviest $\delta^{18} \mathrm{O}$ values which they assumed to be derived from the least altered specimens. This indicated temperatures rising through the Albian, Cenomanian and Turonian and peaking in the Coniacian-Santonian, a conclusion based, however, on a flimsy data set for the latter interval, this followed by a decline in the CampanianMaastrichtian. However, inspection of the maximum palaeotemperature trends discernible from New Zealand and Australian data shows a clear Cretaceous optimum at the Cenomanian-Turonian boundary. This case clearly indicates that in the absence of reliable criteria for accepting or rejecting particular 
isotopic determinations, palaeoclimatic determinations from belemnites can be subjective and influenced by prior interpretations.

The most intriguing and probably most reliable data set is that of Kolodny \& Raab (1988), who investigated the oxygen-isotopic composition of fish teeth from the Cretaceous of Israel; phosphate is not prone to the diagenetic problems that beset skeletal carbonate and potentially provides a more reliable signal. Their results showed an unambiguous palaeotemperature maximum at the Cenomanian-Turonian boundary with estimated palaeotemperatures of 32 to $33^{\circ}$ for a shallow tropical sea situated about $10^{\circ}$ north of the Equator. This compares well with the value of 27 to $28^{\circ} \mathrm{C}$ for the English Chalk Sea during the same interval (Fig. 12).

At first glance the composite oxygen-isotope data of Douglas \& Savin (1975), using various microfossil groups from North Pacific DSDP sites such as Hess, Magellan and Shatsky rises, show a warming trend through the Barremian-Aptian and Albian with climatic decline thereafter. However, both the benthonic foraminifera and the nannofossils indicate a climatic optimum at the Cenomanian-Turonian boundary, although the record is flawed by patchy coverage of these stages due to incomplete core recovery. It is only the planktonic foraminiferal data that apparently indicate a thermal maximum in the Albian but the lack of samples in the three ensuing stages precludes confirmation of this; indeed the other micropalaeontological data indicate otherwise. It should be noted, however, that both Shatsky Rise and Hess Rise crossed the Equator during CenomanianTuronian boundary time (Lancelot \& Larson, 1975; Lancelot, 1978; Jenkyns, 1980; Schlanger et al. 1987), so it could be argued that the palaeotemperature results indicate a phenomenon spatial rather than temporal. The more limited data set of Boersma \& Shackleton (1981) from southern Hess Rise and the western mid-Pacific Mountains show a general climatic decline from Turonian times onward with slight recovery in the latest Maastrichtian.

Although compilations of isotopic palaeotemperature data show discrepancies in the timing of a mid-Cretaceous thermal maximum (see, e.g. Hudson $\&$ Anderson, 1989) we would argue that all oxygenisotope data, wherever collected from mid- to Upper Cretaceous strata, either indicate or are consistent with the hypothesis that there was a warming trend up to the Cenomanian-Turonian boundary followed by climatic deterioration at least until the latest Maastrichtian. Such a trend would have implications for the solubility of oxygen in ocean waters (see, e.g. Berger, 1979) and could be another factor promoting carbon-rich deposition during Cenomanian-Turonian boundary time.

If, as suggested here, the oxygen-isotope data from the English Chalk reflect a global signal of climatic change, then confirmation can only come from detailed isotope stratigraphy from a variety of Cretaceous sections and cores around the world. The relationship between episodes of excess carbon burial, positive carbon-isotope excursions and ensuing climatic decline may turn out to be common throughout geological history. The results documented here certainly suggest that the Cenomanian-Turonian boundary represents a major turning point in the climatic history of the earth.

Given that the mid-Cretaceous may have witnessed exceptionally vigorous volcanic degassing (Arthur, Dean \& Schlanger, 1985; Larson, 1991), greenhouse climates may have been characteristic of the Period, even though much of the excess $\mathrm{CO}_{2}$ may have been fixed as carbon-rich shales at various times during the Aptian and Albian (Arthur et al. 1990). If the Cenomanian-Turonian Oceanic Anoxic Event marks the onset of global cooling then extraction rates of $\mathrm{CO}_{2}$ must have outweighed production rates from this time on, hence indicating the declining importance of global volcanic activity during the Late Cretaceous.

Acknowledgements. This work was largely supported by a grant from BP Research to study the Mesozoic stratigraphy of British basins. Julie Cartlidge operated the PRISM mass spectrometer at Oxford on which all the isotopic data were generated.

\section{References}

Anderson, T. F. \& ArThur, M. A. 1983. Stable isotopes of oxygen and carbon and their application to sedimentologic and paleoenvironmental problems. In Short Course, Society of Economic Paleontologists and Mineralogists (contributors M. A. Arthur, T. F. Anderson, I. R. Kaplan, J. Veizer and L. S. Land), pp. 1-151, Chapter 1.

Arthur, M. A. \& Dean, W. E. 1986. Cretaceous paleoceanography of the western North Atlantic. In The Geology of North America, $M$, the western North Atlantic region (eds P. R. Vogt and B. E. Tucholke), pp. 617-30. Geological Society of America.

Arthur, M. A., Dean, W. E. \& Pratt, L. M. 1988. Geochemical and climatic effects of increased marine organic carbon burial at the Cenomanian/Turonian boundary. Nature 335, 714-17.

Arthur, M. A., Dean, W. E. \& Schlanger, S. O. 1985. Variations in the global carbon cycle during the Cretaceous related to climate, volcanism, and changes in atmospheric $\mathrm{CO}_{2}$. In The Carbon Cycle and Atmospheric $\mathrm{CO}_{2}$ : Natural Variations Archean to Present. (eds E. T. Sundquist and W. S. Broecker), pp. 504-29.

ArThur, M. A. \& Fischer, A. G. 1977. Upper CretaceousPaleocene magnetic stratigraphy at Gubbio, Italy. I. Lithostratigraphy and sedimentology. Bulletin of the Geological Society of America 88, 367-71.

Arthur, M. A., Jenkyns, H. C., Brumsack, H. \& SCHLANGER, S. O. 1990. Stratigraphy, geochemistry, and paleoceanography of organic-carbon-rich Cre- 
taceous sequences. In Cretaceous Resources, Events and Rhythms (eds R. N. Ginsburg and B. Beaudoin), pp. 75-1 19. NATO ASI Series, no. 304. Dordrecht: Kluwer Academic Publishers.

Arthur, M. A. \& Natland, J. H. 1979. Carbonaceous sediments in the North and South Atlantic: the role of salinity in stable stratification of Early Cretaceous basins. In Deep drilling results in the Atlantic Ocean: continental margins and paleoenvironment (eds $M$. Talwani, W. Hay and W. B. F. Ryan), pp. 375-401. Maurice Ewing Series 3. Washington: American Geophysical Union.

Arthur, M. A. \& Premoli-Silva, 1. 1982. Development of widespread organic carbon-rich strata in the mediterranean Tethys. In Nature and Origin of Cretaceous Carbon-rich Facies (eds S. O. Schlanger and M. B. Cita), pp. 7-54. London: Academic Press.

Arthur, M. A., Schlanger, S. O. \& Jenkyns, H. C. 1987 The Cenomanian-Turonian Oceanic Anoxic Event. II Palaeoceanographic controls on organic-matter production and preservation. In Marine Petroleum Source Rocks (eds J. Brooks and A. J. Fleet), pp. 401-20. Geological Society of London, Special Publication no. 26.

Arthurton, R. S., Booth, S. J., Morigi, A. N., Abbott, M. A. W. \& WooD, C. J. (In press.) The Geology of the country around Great Yarmouth. Memoir of the British Geological Survey, Sheet 162 (England and Wales).

Bailey, H. W., Gale, A. S., Mortimore, R. N., Swiecicki, A. \& WooD, C. J. 1983. The Coniacian-Maastrichtian stage boundaries of the United Kingdom, with particular reference to southern England. Newsletters on Stratigraphy 12, 19-42.

Bailey, H. W., Gale, A. S., Mortimore, R. N., Swiecicki, A. \& Wood, C. J. 1984. Biostratigraphical criteria for the recognition of the Coniacian to Maastrichtian stage boundaries in the Chalk of north-west Europe, with particular reference to southern England. Bulletin of the Geological Society of Denmark 33, 31-9.

BalleY, H. W. \& HART, M. B. 1979. The correlation of the Early Senonian in Western Europe. In Aspekte der Kreide Europas (ed. J. Wiedmann), pp. 159-71. International Union of Geological Sciences, Series A, no. 6. Stuttgart: E. Schweizerbart'sche Verlagsbuchhandlung.

BARR, F. T. 1962. Upper Cretaceous planktonic foraminiferida from the Isle of Wight. Palaeontology 4, 552-80.

Berger, W. H. 1979. Impact of deep-sea drilling on paleoceanography. In Deep drilling results in the Atlantic Ocean: continental margins and paleoenvironment (eds M. Talwani, W. Hay and W. B. F. Ryan), pp. 297-314. Maurice Ewing Series 3. Washington, D.C.: American Geophysical Union.

Berger, W. H. \& VINCENT, E. 1986. Deep-sea carbonates: reading the carbon-isotope signal. Geologische Rundschau 75, 249-69.

Bernoulli, D. 1972. North Atlantic and Mediterranean Mesozoic facies: a comparison. In Initial Reports of the Deep Sea Drilling Project, vol. 11 (C. D. Hollister, J. I. Ewing et al.), pp. 801-79. Washington D.C.: U.S. Government Printing Office.

Bernoulli, D. \& Jenkyns, H. C. 1974. Alpine, Mediterranean and Central Atlantic Mesozoic Facies in relation to the early evolution of the Tethys. In Modern and Ancient Geosynclinal Sedimentation (eds R. H. Dott and R. H. Shaver), pp. 129-60. Special Publication of the Society of Economic Paleontologists and Mineralogists no. 19.

Birkelund, T., Hancock, J. M., Hart, M. B., Rawson, P. F., Remane, J., Robaszynski, F., SChmid, F. \& Surlyk, F. 1984. Cretaceous Stage Boundaries-proposals Bulletin of the Geological Society of Denmark 33, 3-20.

Boersma, A. \& Shackleton, N. J. 1981. Oxygen- and carbon-isotope variations and planktonic-foraminifer depth habitats, Late Cretaceous to Paleocene, central Pacific, Deep Sea Drilling Project Sites 463 and 465. In Initial Reports of the Deep Sea Drilling Project, vol. 62 (J. Thiede, T. Vallier et al.), pp. 513-26. Washington D.C.: U.S. Government Printing Office.

BowEn, R. 1966. Paleotemperature Analysis. Amsterdam, London, New York: Elsevier, 265 pp.

BRALOWER, T. 1988. Calcareous nannofossil biostratigraphy and assemblages of the Cenomanian-Turonian boundary: implications for the origin and timing of oceanic anoxia. Paleoceanography 3, 275-316.

Bromley, R. G. 1979. Chalk and bryozoan limestone: facies, sediments, and depositional environments. In Cretaceous-Tertiary boundary events. 1. The Maastrichtian and Danian of Denmark (eds T. Birkelund and R. G. Bromley), pp. 16-32. Copenhagen.

Bromley, R. G. \& Gale, A. S. 1982. The lithostratigraphy of the English Chalk Rock. Cretaceous Research 3, 273-306.

Brumsack, H. J. \& Thurow, J. 1986. The geochemical facies of black shales from the Cenomanian/Turonian Boundary Event (CTBE). In Biogeochemistry of Black Shales (eds E. T. Degens, P. A. Meyers and S. C. Brassell), pp. 247-265. Mitteilungen aus dem Geologisch-Paläontologischen Institut der Universität Hamburg no. 60.

BRYDONE, R. M. 1906. Further notes on the stratigraphy and fauna of the Trimingham Chalk. Geological Magazine 43, 13-22; 72-8; 124-31; 289-300.

BRYDONE, R. M. 1908. On the subdivisions of the Chalk of Trimingham. Quarterly Journal of the Geological Society of London 63, 401-11.

BRYDONE, R. M. 1914. The zone of Offaster pilula in the southern English Chalk. Parts I-IV. Geological Magazine 51, 359-69; 405-11; 449-57; 509-13.

BRYDONE, R. M. 1938. On the correlation of some of the Norfolk exposures of Chalk with Belemnitella mucronata. London, $15 \mathrm{pp}$.

Burdett, J. W., Arthur, M. A. \& Lohmann, K. C. 1990 Do the carbon and oxygen signatures of inoceramid bivalves reflect the isotopic signature of Cretaceous seawater? Eos 71, 1352-3.

BURNETT, J. 1989. A new nannofossil zonation scheme for the Boreal Campanian. International Nannofossil Association Newsletter 12, 67-70.

Carter, D. J. \& HarT, M. B. 1977. Aspects of midCretaceous stratigraphic micropalaeontology. Bulletin of the British Museum of Natural History (Geology) 29, $1-135$.

Clarke, R. F. A. \& Verdier, J.-P. 1967. An investigation of microplankton assemblages from the Chalk of the Isle of Wight. Verhandelingen der koninklijke Nederlandse Akademie van Wetenschappen, Afdeeling Naturkunde, Eerste Reeks 24, 1-96.

Clauser, S. 1987. Évolution de la composition isotopique de l'oxygène des carbonates durant le CampanienMaastrichtien. Données préliminaires issues de la série 
de Bidart (Pyrénées-Atlantiques). Comptes Rendus de I Académie des Sciences, Paris 304, Série II, 579-84.

Cool, T. E. 1982. Sedimentological evidence concerning the palaeoceanography of the Cretaceous western North Atlantic Ocean. Palaeogeography, Palaeoclimatology, Palaeoecology 39, 1-35.

Corfield, R. M., Cartlidge, J. E., Premoli-Silva, I. \& Housley, R. A. 1991. Oxygen and carbon isotope stratigraphy of the Palaeogene and Cretaceous limestones in the Bottaccione Gorge and the Contessa Highway sections, Umbria, Italy. Terra Nova 3, 414-22.

Corfield, R. M., Hall, M. A. \& Brasier, M. D. 1990. Stable isotope evidence for foraminiferal habitats during the development of the Cenomanian/Turonian oceanic anoxic event. Geology 18, 175-8.

Cresta, S., Monechi, S. \& Parisi, G. 1989. MesozoicCenozoic stratigraphy in the Umbria-Marche area. Memorie descrittive della Carta geologica d'Italia no. $39,185 \mathrm{pp}$.

Crumière, J.-P., Crumière-Airaud, C., Espitalié, J. \& Cotillon, P. 1990. Global and regional controls on potential source-rock deposition and preservation: the Cenomanian-Turonian Oceanic Anoxic Event (CTOAE) on the European Tethyan Margin (southeastern France). In Deposition of Organic Facies (ed. A. Y. Huc), pp. 107-18. American Association of Petroleum Geologists, Studies in Geology no. 30.

Crux, J.A. 1982. Upper Cretaceous (Cenomanian to Campanian) calcareous nannofossils. In $A$ stratigraphical index of calcareous nannofossils (ed. A. R. Lord), pp. 81-135. Chichester: Ellis Horwood for the British Micropalaeontological Society.

Dickson, J. A. D. 1991. Disequilibrium carbon and oxygen isotope variations in natural calcite. Nature 353, 842-4.

Douglas, R. G. \& Savin, S. M. 1975. Oxygen and carbon isotope analyses of Tertiary and Cretaceous microfossils from Shatsky Rise and other sites in the North Pacific Ocean. In Initial Reports of the Deep Sea Drilling Project, vol. 32 (R. L. Larson, R. Moberly et al.), pp. 509-20.

Einsele, G. \& Wiedmann, J. 1982. Turonian black shales in the Moroccan coastal basins: first upwelling in the Atlantic Ocean? In Geology of the northwest African continental Margin (eds U. von Rad, K. Hinz, M. Sarnthein \& E. Seibold), pp. 396-414. Berlin, Heidelberg, New York: Springer.

ERNST, G. 1963. Stratigraphische und gesteinchemische Untersuchungen im Santon und Campan von Lagerdorf. Mitteilungen aus dem Geologischen Staatsinstitut in Hamburg 32, 71-127.

Farrimond, P., Eglinton, G., Brassell, S. C. \& Jenkyns, H. C. 1990. The Cenomanian-Turonian anoxic event in Europe: an organic geochemical study. Marine and Petroleum Geology 7, 75-89.

Flexer, A., Rosenfeld, A., Lipson-Benitah, S. \& HoniGSTEIN, A. 1986. Relative sea level changes during the Cretaceous in Israel. Bulletin of the American Association of Petroleum Geologists 70, 1685-99.

Gale, A. S. 1980. Penecontemporaneous folding, sedimentation and erosion in Campanian Chalk near Portsmouth, England. Sedimentology 27, 137-51.

GaLE, A. S. 1989. A Milankovitch scale for Cenomanian time. Terra Nova 1, 420-5.

Gale, A. S. \& CleEvely, R. J. 1989. Arthur Rowe and the zones of the White Chalk of the English coast. Proceedings of the Geologists' Association 100, 419-31.

Gale, A. S., Jenkyns, H. C., Kennedy, W. J. \& Corfield, R. M. 1993. Chemostratigraphy versus biostratigraphy: data from around the CenomanianTuronian boundary. Journal of the Geological Society, London 150, 29-32.

Gale, A. S., Wood, C. J. \& Bromley, R. G. 1987. The lithostratigraphy and marker bed correlation of the White Chalk (Late Cenomanian-Campanian) of southern England. Mesozoic Research 1, 107-18.

Gallois, R. W. \& MORTER, A. A. 1976. IGS boreholes 1975. East Anglia and South-East England District: Mundesley (132) sheet; Trunch borehole (TG 29333455). Report of the Institute of Geological Sciences 76/10, 8-10.

Graciansky, P. C. de, Brosse, E., Deroo, G., Herbin, J. P., Montadert, L., Müller, C., Sigal, J. \& Schaaf, A. 1982. Les formations d'âge crétacé de l'Atlantique Nord et leur matière organique: paléogéographie et milieux de dépôt. Revue de l'Institut français du Pétrole 37, 275-337.

Graciansky, P. C. De, Deroo, G., Herbin, J. P., Jacquin, T., Magniez, F., Montadert, L., Müller, C., Ponsot, C., SchaAf, A. \& Sigal, J. 1986. Ocean-wide stagnation episodes in the Late Cretaceous. Geologische Rundschau 75, 17-41.

Håkansson, E., Bromley, R. \& Perch-Nielsen, K. 1974. Maastrichtian chalk of north-west Europe - a pelagic shelf sediment. In Pelagic Sediments: on Land and under the Sea (eds K. J. Hsü and H. C. Jenkyns), pp. 211-33. Special Publication of the International Association of Sedimentologists no. 1.

HanCOCK, J. M. 1975. The petrology of the Chalk. Proceedings of the Geologists' Association 86, 499-535.

Hancock, J. M. 1989. Sea-level changes in the British region during the Late Cretaceous. Proceedings of the Geologists' Association 100, 565-94.

Hancock, J. M. 1991. Ammonite scales for the Cretaceous System. Cretaceous Research 12, 259-91.

Hancock, J. M. \& Kauffman, E. G. 1979. The great transgressions of the Late Cretaceous. Journal of the Geological Society, London 136, 175-86.

HaQ, B. U., Hardenbol, J. \& VaIL, P. R. 1988. Mesozoic and Cenozoic chronostratigraphy and cycles of sea level change. In Sea level changes: an integrated approach (eds C. K. Wilgus, B. S. Hastings, H. Posamentier, J. van Wagoner, C. A. Ross and C. G. St. Kendall), pp. 71-108. Special Publication of the Society of Economic Paleontologists and Mineralogists no. 42.

Hart, M. B., Bailey, H. W., Crittenden, S., Fletcher, B. N., Price, R. J. \& SwIECICKI, A. 1989. Cretaceous. In Stratigraphical Atlas of Fossil Foraminifera, 2nd ed. (eds D. G. Jenkins and J. W. Murray), pp. 273-371. Chichester: Ellis Horwood for the British Micropalaeontological Society.

HaRT, M. B. \& Leary, P. N. 1989. The stratigraphic and palaeogeographic setting of the late Cenomanian 'anoxic' event. Journal of the Geological Society, London 146, 305-10.

Herbin, J. P., Montadert, L., Müller, C., Gomez, R., Thurow, J. \& WiedmanN, J. 1986. Organic-rich sedimentation at the Cenomanian-Turonian boundary in oceanic and coastal basins in the North Atlantic and 
Tethys. In North Atlantic Palaeoceanography (eds C. P. Summerhayes and N. J. Shackleton), pp. 389-422. Geological Society of London, Special Publication no. 21.

Herbin, J. P., Magniez-Jannin, F. \& Müller, C. 1986. Mesozoic organic-rich sediments in the South Atlantic: distribution in time and space. In Biogeochemistry of Black Shales (eds E. T. Degens, P. A. Meyers and S. C. Brassell), pp. 71-97. Mitteilungen aus dem GeologischPaläontologischen Institut der Universität Hamburg no. 60 .

Hilbrecht, H. \& Hoefs, J. 1986. Geochemical and palaeontological studies of the $\delta^{13} \mathrm{C}$ anomaly in boreal and north Tethyan Cenomanian-Turonian sediments in Germany and adjacent areas. Palaeogeography, Palaeoclimatology, Palaeoecology 53, 169-89.

Hilbrecht, H., Arthur, M. A. \& Schlanger, S. O. 1986. The Cenomanian-Turonian boundary event: sedimentary, faunal and geochemical criteria developed from stratigraphic studies in Germany. In Global Bio-Events, Lecture Notes in Earth Sciences (ed. O. Walliser), pp. 345-51. Berlin, Heidelberg: Springer.

Honigstein, A., Lipson-Benitah, S., Conway, B., Flexer, A. \& Rosenfeld, A. 1989. Mid-Turonian anoxic event in Israel-a multidisciplinary approach. Palaeogeography, Palaeoclimatology, Palaeoecology 69, 103-12.

HUDSON, J. D. 1967. Speculations on the depth relations of calcium carbonate solution in Recent and ancient seas. Marine Geology 5, 473-80.

Hudson, J. D. 1977. Stable isotopes and limestone lithification. Journal of the Geological Society, London 133, 637-60.

Hudson, J. D. \& ANDERSon, T. F. 1989. Ocean temperatures and isotopic compositions through time. Transactions of the Royal Society of Edinburgh: Earth Sciences 80, 183-92.

Irwin, H., CuRTIS, C. D. \& Coleman, M. L. 1977. Isotopic evidence for source of diagenetic carbonates formed during burial of organic-rich sediments. Nature 269 , 209-13.

Jarvis, I., Carson, G. A., CoOper, M. K. E., hart, M. B., LeARy, P. N., Tocher, B. A., Horne, D. \& Rosenfeld, A. 1988. Microfossil assemblages and the Cenomanian-Turonian (late Cretaceous) oceanic anoxic event. Cretaceous Research 9, 3-103.

Jarvis, I. \& Tocher, B. A. 1987. Field Meeting: the Cretaceous of SE Devon, 14th-16th March, 1986. Proceedings of the Geologists' Association 98, 51-66.

JARVIS, I. \& WoODROOF, P. B. 1984. Stratigraphy of the Cenomanian and basal Turonian (Upper Cretaceous) between Branscombe and Seaton, SE Devon, England. Proceedings of the Geologists' Association 95, 193-215.

Jeans, C. V., Long, D., Hall, M. A., Bland, D. J. \& CORNFORD, C. 1991. The geochemistry of the Plenus Marls at Dover, England: evidence of fluctuating oceanographic conditions and of glacial control during the development of the Cenomanian-Turonian $\delta^{13} \mathrm{C}$ anomaly. Geological Magazine 128, 603-32.

JEFFERIES, R. P. S. 1962. The palaeoecology of the Actinocamax plenus subzone (lowest Turonian) in the AngloParis Basin. Palaeontology 4, 609-47.

JefFERIES, R.P.S. 1963. The stratigraphy of the Actinocamax plenus subzone (Turonian) in the Anglo-Paris Basin. Proceedings of the Geologists' Association 74, $1-34$.
Jenkyns, H.C. 1980. Cretaceous anoxic events: from continents to oceans. Journal of the Geological Society, London 137, 171-88.

Jenkyns, H.C. 1985. The Early Toarcian and Cenomanian-Turonian anoxic events in Europe: comparisons and contrasts. Geologische Rundschau 74, 505-18.

Jenkyns, H. C. 1988. The early Toarcian (Jurassic) anoxic event: stratigraphic, sedimentary, and geochemical evidence. American Journal of Science 288, 101-51.

JENKYNs, H. C. 1991. Impact of Cretaceous sea level rise and anoxic events on the Mesozoic carbonate platform of Yugoslavia. Bulletin of the American Association of Petroleum Geologists 75, 1007-17.

Jenkyns, H. C. \& Clayton, C. J. 1986. Black shales and carbon isotopes in pelagic sediments from the Tethyan Lower Jurassic. Sedimentology 33, 87-106.

Johansen, M. B. \& SURLYK, F. 1990. Brachiopods and the stratigraphy of the Upper Campanian and Lower Maastrichtian Chalk of Norfolk, England. Palaeontology 33, 823-72.

JøRGENSEN, N. O. 1987. Oxygen and carbon isotope compositions of Upper Cretaceous chalk from the Danish sub-basin and the North Sea Central Graben. Sedimentology 34, 559-70.

KENNEDy, W. J. 1969. The correlation of the Lower Chalk of south-east England. Proceedings of the Geologists' Association 80, 459-560.

Kennedy, W. J. \& Cobban, W. A. 1991. Stratigraphy and interregional correlation of the Cenomanian-Turonian transition in the Western Interior of the United States near Pueblo, Colorado, a potential boundary stratotype for the base of the Turonian stage. Newsletters on Stratigraphy 24, 1-33.

Kennedy, W. J. \& OdIN, G. S. 1982. The Jurassic and Cretaceous time scale in 1981. In Numerical dating in stratigraphy (ed. G. S. Odin), pp. 557-92, Chichester: John Wiley.

Kolodny, Y. \& RAAB, M. 1988. Oxygen isotopes in phosphatic fish remains from Israel; paleothermometry of tropical Cretaceous and Tertiary shelf waters. Palaeogeography, Palaeoclimatology, Palaeoecology 64, 59-67.

Kuhnt, W., Thurow, J., Herbin, J. P. \& Wiedmann, J. 1986. Oceanic anoxic conditions around the Cenomanian/Turonian boundary and the response of the biota. In Biogeochemistry of Black Shales (eds E. T. Degens, P. A. Meyers and S. C. Brassell), pp. 205-46. Mitteilungen aus dem Geologisch-Paläontologischen Institut der Universität Hamburg no. 60.

Kuhnt, W., Herbin, J. P., Thurow, J. \& Wiedmann, J. 1990. Distribution of Cenomanian-Turonian organic facies in the western Mediterranean and along the adjacent Atlantic margin. In Deposition of organic facies (ed. A. Y. Huc), pp. 133-60. American Association of Petroleum Geologists, Studies in Geology, no. 30.

LANCELOT, Y. 1978. Relations entre évolution sédimentaire et tectonique de la Plaque pacifique depuis le Crétacé inferieur. Mémoire de la Société géologique de France no. 134,40 pp.

LANCELOT, Y. \& LARSON, R. L. 1975. Sedimentary and tectonic evolution of the northwestern Pacific. In Initial Reports of the Deep Sea Drilling Project, vol. 32 (R. L. 
Larson, R. Moberly et al.), pp. 925-39. Washington D.C.: U.S. Government Printing Office.

LARSON, R. L. 1991. Geological consequences of superplumes. Geology 19, 963-6.

Lipson-Benitah, S., Flexer, A., Rosenfeld, A., HonigSTEIN, A., Conway, B. \& ERIS, H. 1990. Dysoxic sedimentation in the Cenomanian-Turonian Daliyya Formation, Israel. In Deposition of organic facies (ed. A. Y. Huc), pp. 27-39. American Association of Petroleum Geologists, Studies in Geology, no. 30.

Lowenstam, H. A. \& Epstein, S. 1954. Paleotemperatures of the post-Aptian Cretaceous as determined by the oxygen isotope method. Journal of Geology 62 (3), 207-48.

Lowrie, W., Channell, J. \& Alvarez, W. 1980. A review of magnetic stratigraphy investigations in Cretaceous pelagic carbonate rocks. Journal of Geophysical Research 85 B, 3597-605.

Maliva, R. G., Dickson, J. A. D. \& Raheim, A. 1991. Modelling of chalk diagenesis (Eldfisk Field, Norwegian North Sea) using whole rock and laser ablation stable isotopic data. Geological Magazine 128, 43-9.

MCArthur, J. M., Thirlwall, M. F., Gale, A. S., Kennedy, W. J., Burnett, J. A., Mattey, D. \& Lord, A. R. 1993. Strontium isotope stratigraphy for the Late Cretaceous: a new curve based on the English Chalk. In High Resolution Stratigraphy (eds E. A. Hailwood and R. B. Kidd), 195-209. Geological Society of London, Special Publication no. 70.

MoNECH, S. 1981. Aptian-Cenomanian calcareous nannoplankton from some sections in the Umbrian Apennines. Rivista italiana di Paleontologia e Stratigrafia 87, 193-226.

MORTIMORE, R. N. 1983. The stratigraphy and sedimentation of the Turonian-Campanian in the Southern Province of England. Zitteliana 10, 27-41.

MoRTimore, R. N. 1986. Stratigraphy of the Upper Cretaceous White Chalk of Sussex. Proceedings of the Geologists' Association 97, 97-139.

MoRtimore, R. N. 1987. Controls on Upper Cretaceous sedimentation in the South Downs, with particular reference to flint distribution. In The scientific study of flint and chert (eds G. de C. Sieveking and M. B. Hart), pp. 21-42. Cambridge University Press.

MORTIMORE, R. N. \& WoOD, C. J. 1986. The distribution of flint in the English Chalk, with particular reference to the 'Brandon Flint Series' and the high Turonian flint maximum. In The scientific study of fint and chert (eds G. de C. Sieveking and M. B. Hart), pp. 7-20. Cambridge University Press.

Naydin, D. P., Teys, R. V. \& Zadorozhnyy, I. K. 1966. Isotopic paleotemperatures of the Upper Cretaceous in the Russian Platform and other parts of the USSR. Geochemistry International 3, 1038-51.

Pacey, N. R. 1984. Bentonites in the Chalk of central eastern England and their relation to the opening of the northeast Atlantic. Earth and Planetary Science Letters 67, 48-60.

Peake, N. B. \& Hancock, J. M. 1961. The Upper Cretaceous of Norfolk. Transactions of the Norfolk and Norwich Naturalists' Society 19, 293-339.

Peake, N. B. \& Hancock, J. M. 1970. The Upper Cretaceous of Norfolk (reprinted with corrigenda and addenda). In The Geology of Norfolk (eds G. P.
Larwood and B. M. Funnell), pp. 293-339. London and Ashford.

Pedersen, T. F. \& Calvert, S. E. 1990. Anoxia vs. productivity: what controls the formation of organiccarbon-rich sediments and sedimentary rocks? Bulletin of the American Association of Petroleum Geologists 74, 454-66.

PELET, R. 1987. A model of organic sedimentation on present-day continental margins. In Marine Petroleum Source Rocks (eds J. Brooks and A. J. Fleet), pp. 167-80. Geological Society of London, Special Publication no. 26.

PHILlips, W. 1821. Remarks on the chalk cliffs in the neighbourhood of Dover, and on the Blue Marle covering the Green Sand, near Folkestone. Transactions of the Geological Society of London 5, 16-51.

Pirrie, D. \& Marshall, J. D. 1990. Diagenesis of Inoceramus and Late Cretaceous paleoenvironmental geochemistry: a case study from James Ross Island, Antarctica. Palaios 5, 336-45.

Pratt, L. M., Arthur, M. A., Dean, W. E. \& Scholle, P. A. 1993. Paleoceanographic cycles and events during the Late Cretaceous in the Western Interior Seaway of North America. In Cretaceous Evolution of the Western Interior Basin of North America (eds W. G. E. Caldwell and E. G. Kauffman), Special Paper of the Geological Association of Canada, in press.

Pratt, L. M., Force, E. R. \& Pomerol, B. 1991. Coupled manganese and carbon-isotopic events in marine carbonates at the Cenomanian-Turonian boundary. Journal of Sedimentary Petrology 61, 370-83.

Pratt, L. M. \& Threlkeld, C. N. 1984. Stratigraphic significance of ${ }^{13} \mathrm{C} /{ }^{12} \mathrm{C}$ ratios in mid-Cretaceous rocks of the Western Interior, U.S.A. In The Mesozoic of middle North America (eds D. F. Stott and D. J. Glass), pp. 305-12. Memoir of the Canadian Society of Petroleum Geologists no. 9.

Premoli-Silva, I. 1977. Upper Cretaceous-Paleocene magnetic stratigraphy at Gubbio, Italy. II. Biostratigraphy. Bulletin of the Geological Society of America 88, 371-4.

Price, F. G. H. 1877. On the beds between the Gault and Upper Chalk near Folkestone. Quarterly Journal of the Geological Society of London 33, 431-48.

Rad, U. von, Thurow, J., HaQ, B. U., Gradstein, F. \& Ludden, J. 1989. Triassic to Cenozoic evolution of the NW Australian continental margin and the birth of the Indian Ocean (preliminary results of ODP Legs 122 and 123). Geologische Rundschau 78, 1189-1210.

Rawson, P. F., Curry, D., Dilley, F. C., HaNCock, J. M., Kennedy, W. J., Neale, J. M., Wood, C. J. \& WorsSAM, B. C. 1978. A correlation of Cretaceous rocks in the British Isles. Special Report of the Geological Society, London no. 9, 70 pp.

RENARD, M. 1986. Pelagic carbonate chemostratigraphy $\left(\mathrm{Sr}, \mathrm{Mg},{ }^{18} \mathrm{O},{ }^{13} \mathrm{C}\right)$. Marine Micropaleontology 10 , 117-64.

Robaszynski, F., Caron, M., Dupuis, C., Amédro, F., González Donoso, J. M., Linares, D., Hardenbol, J., Gartner, S., Calandra, F. \& Deloffre, R. 1990. A tentative integrated stratigraphy in the Turonian of central Tunisia: Formations, Zones and sequential stratigraphy in the Kalaat Senan area. Bulletin des 
Centres de Recherche Exploration-Production ElfAquitaine 14, 213-384.

Robaszynski, F., Juignet, P., Gale, A. S., AmÉdro, F. \& HARDENBOL, J. 1992. Sequence stratigraphy in the Upper Cretaceous of the Anglo-Paris Basin, exemplified by the Cenomanian stage. Abstracts, Sequence Stratigraphy of European Basins, Dijon, France, 80-81.

Robinson, N. D. 1986. Lithostratigraphy of the Chalk Group of the North Downs, south-east England. Proceedings of the Geologists' Association 97, 141-170.

Rowe, A. W. 1899. An analysis of the Genus Micraster, as determined by rigid zonal collecting from the Zone of Rhynchonella cuvieri to that of Micraster cor-anguinum. Quarterly Journal of the Geological Society of London 55, 494-547.

Rowe, A. W. 1900. The zones of the White Chalk of the English coast. I. Kent and Sussex. Proceedings of the Geologists' Association 16, 289-368.

Rowe, A. W. 1908. The zones of the White Chalk of the English coast. V. The Isle of Wight. Proceedings of the Geologists' Association 20, 209-352.

Ryan, W. B. F. \& Cita, M. B. 1977. Ignorance concerning episodes of ocean-wide stagnation. Marine Geology 23, 197-215.

SaELEN, G. 1989. Diagenesis and construction of the belemnite rostrum. Palaeontology 32, 765-98.

Saflen, G. \& Karstang, T. V. 1989. Chemical signatures of belemnites. Neues Jahrbuch für Geologie und Paläontologie, Abhandlungen 177, 336-46.

Sass, E., Bein, A. \& Almogi-Labin, A. 1991. Oxygenisotope composition of diagenetic calcite in organicrich rocks: evidence for ${ }^{18} \mathrm{O}$ depletion in marine anaerobic pore water. Geology 19, 839-42.

SAVIN, S. M. 1977. History of the earth's surface temperature during the last 100 million years. In Annual Reviews of Earth and Planetary Sciences (eds F. A. Donath, F. G. Stehli and G. W. Wetherill), pp. 319-55. Palo Alto, California: Annual Reviews Inc.

Schlanger, S. O., ARThur, M. A., Jenkyns, H. C. \& SCholle, P.A. 1987. The Cenomanian-Turonian Oceanic Anoxic Event. I. Stratigraphy and distribution of organic carbon-rich beds and the marine $\delta^{13} \mathrm{C}$ excursion. In Marine Petroleum Source Rocks (eds J. Brooks and A. J. Fleet), 371-99. Geological Society of London, Special Publication no. 26.

Schlanger, S. O. \& Jenkyns, H. C. 1976. Cretaceous oceanic anoxic events: causes and consequences. Geologie en Mijnbouw 55, 179-84.

Scholle, P. A. 1974. Diagenesis of Upper Cretaceous chalks from England, Northern Ireland, and the North Sea. In Pelagic Sediments: on Land and under the Sea (eds K. J. Hsü and H. C. Jenkyns), pp. 177-210. Special Publication of the International Association of Sedimentologists no. 1.

Scholle, P. A. 1977. Chalk diagenesis and its relation to petroleum exploration: oil from chalk, a modern miracle? Bulletin of the American Association of Petroleum Geologists 61, 982-1009.

Scholle, P. A. \& ARThur, M. 1980. Carbon isotope fluctuations in Cretaceous pelagic limestones: potential stratigraphic and petroleum exploration tool. Bulletin of the American Association of Petroleum Geologists 64, 67-87.

Scholle, P. A. \& Halley, R. B. 1985. Burial diagenesis: out of sight, out of mind! In Carbonate Cements (eds $\mathrm{N}$.
Schneidermann and P. M. Harris), pp. 309-34. Special Publication of the Society of Economic Paleontologists and Mineralogists no. 36.

SChÖnfeld, J., Sirocko, F. \& JøRgensen, N. O. 1991. Oxygen isotope composition of Upper Cretaceous chalk at Lägerdorf (NW Germany): its original environnment signal and palaeotemperature interpretation. Cretaceous Research 12, 27-46.

Schulz, M.-G. 1979. Morphometrisch-variationsstatistische Untersuchungen zur Phylogenie der Belemnitengattung Belemnella im Untermaastricht NW-Europas. Geologische Jahrbuch A 47, 157 pp.

SeIglie, G. A. \& BaKeR, M. B. 1984. Relative sea-level changes during the middle and Late Cretaceous from Zaire to Cameroon (central West Africa). In Interregional unconformities and hydrocarbon accumulation (ed. J. S. Schlee), pp. 81-8. Memoir of the American Association of Petroleum Geologists no. 36.

Shackleton, N. J. 1986. Paleogene stable isotope events. Palaeogeography, Palaeoclimatology, Palaeoecology 57, 91-102.

Shackleton, N. J. 1987. The carbon isotope record of the Cenozoic: history of organic carbon burial and of oxygen in the ocean and atmosphere. In Marine Petroleum Source Rocks (eds J. Brooks and A. J. Fleet), pp. 423-34. Geological Society of London, Special Publication no. 26.

SLITER, W. V. 1989. Biostratigraphic zonation for Cretaceous planktonic foraminifers examined in thin section. Journal of Foraminiferal Research 19, 1-19.

SPAeTh, C., Hoefs, J. \& Vetrer, U. 1971. Some aspects of isotopic composition of belemnites and related paleotemperatures. Bulletin of the Geological Society of America 82, 3139-50.

Stevens, G. R. \& Clayton, R. N. 1971. Oxygen isotope studies on Jurassic and Cretaceous belemnites from New Zealand and their biogeographic significance. New Zealand Journal of Geology and Geophysics 14, 829-97.

SUESS, E. 1888. Das Antlitz der Erde, vol. 2. Prague, Vienna: F. Tempsky; Leipzig: G. Freytag, 703 pp.

SUMmerhayes, C. P. 1987. Organic-rich Cretaceous sediments from the North Atlantic. In Marine Petroleum Source Rocks (eds J. Brooks and A. J. Fleet), 301-16. Geological Society of London, Special Publication no. 26.

Teys (TeIS), R. V., Chupakhin, M. S. \& NAYdin (NAIDIN), D. P. 1957. Determination of paleotemperatures from the isotopic composition of oxygen in calcite of certain Cretaceous fossil shells from Crimea. Geochemistry 1957, 323-9.

Thierstein, H. R. \& Roth, P. H. 1991. Stable isotopic and carbonate cyclicity in Lower Cretaceous deep-sea sediments: dominance of diagenetic effects. Marine Geology 97, 1-34.

Thurow, J., Kunnt, W. \& WiedmanN, J. 1982. Zeitlicher und paläogeographischer Rahmen der Phthanit- und Black Shale-Sedimentation in Marokko. Neues Jahrbuch für Geologie und Paläontologie, Abhandlungen 165, 147-76.

Tribovillard, N.-P., Stephan, J.-F., Manivit, H., Reyre, Y., Cotillon, P. \& JaUtéE, E. 1991. Cretaceous black shales of Venezuelan Andes: preliminary results on stratigraphy and paleoenvironmental interpretations. 
Palaeogeography, Palaeoclimatology, Palaeoecology 81, 313-21.

TRöGER, K. A. 1989. Problems of Upper Cretaceous inoceramid biostratigraphy and palaeobiogeography in Europe and Western Asia. In Cretaceous of western Tethys (ed. J. Wiedmann), pp. 911-30. Proceedings 3rd International Cretaceous Symposium, Tübingen 1987. Stuttgart: E. Schweizerbart'sche Verlagsbuchhandlung.

TUCKOLKE, B. E. \& VoGT, P. R. 1979. Initial Reports of the Deep Sea Drilling Project, vol. 43. Washington, D.C.: U.S. Government Printing House, 1115 pp.

Urey, H. C., Lowenstam, H. A., Epstein, S. \& MCKinney, C. R. 1951. Measurement of paleotemperatures and temperatures of the Upper Cretaceous of England, Denmark, and the southeastern United States. Bulletin of the Geological Society of America 62, 399-416.

VaIL, P. R., Mitchum, R. M. \& Thompson III, S. 1977. Seismic stratigraphy and global changes of sea level, part 4: global cycles of relative changes of sea level. In Seismic stratigraphy - applications to hydrocarbon exploration (ed. C. E. Payton), pp. 83-97. Memoir of the American Association of Petroleum Geologists, no. 26.

VeIzer, J. 1974. Chemical diagenesis of belemnite shells and possible consequences for paleotemperature determinations. Neues Jahrbuch für Geologie und Paläontologie, Abhandlungen 147, 91-111.

Vincent, E. \& Berger, W. H. 1985. Carbon dioxide and polar cooling in the Miocene: the Monterey Hypothesis. In The Carbon Cycle and Atmospheric $\mathrm{CO}_{2}:$ Natural
Variations Archean to Present (eds E. T. Sundquist and W. S. Broecker), pp. 455-68. American Geophysical Union, Geophysical Monograph no. 32.

VinCENT, E. \& KillingeY, J. S. 1985. Oxygen and carbon isotope record for the early and middle Miocene in the central equatorial Pacific (leg 85) and paleoceanographic implications. In Initial Reports of the Deep Sea Drilling Project vol. 85 (L. Mayer, F. Theyer et al.), pp. 749-69. Washington, D.C.: U.S. Government Printing Office.

WEIMER, R. J. 1984. Relation of unconformities, tectonics, and sea-level changes, Cretaceous of Western Interior, U.S.A. In Interregional unconformities and hydrocarbon accumulation (ed. J. S. Schlee), pp. 7-35. Memoir of the American Association of Petroleum Geologists no. 36.

WeISSERT, H. 1989. C-isotope stratigraphy, a monitor of paleoenvironmental change: a case study from the Early Cretaceous. Surveys in Geophysics 10, 1-61.

WeisSERT, H. \& LinI, A. 1991. Ice age interludes during the time of Cretaceous greenhouse climate. In Controversies in modern Geology (eds D. W. Müller, J. A. McKenzie and H. Weissert), pp. 173-191. London: Academic Press.

WhItE, H. J. O. 1921. A short account of the geology of the Isle of Wight. Memoirs of the Geological Survey, England and Wales. His Majesty's Stationery Office, London. $219 \mathrm{pp}$.

Wood, C. J. \& SMITH, E. G. 1978. Lithostratigraphical classification of the Chalk in north Yorkshire. Proceedings of the Yorkshire Geological Survey 42, 263-87. 
Appendix

(a)

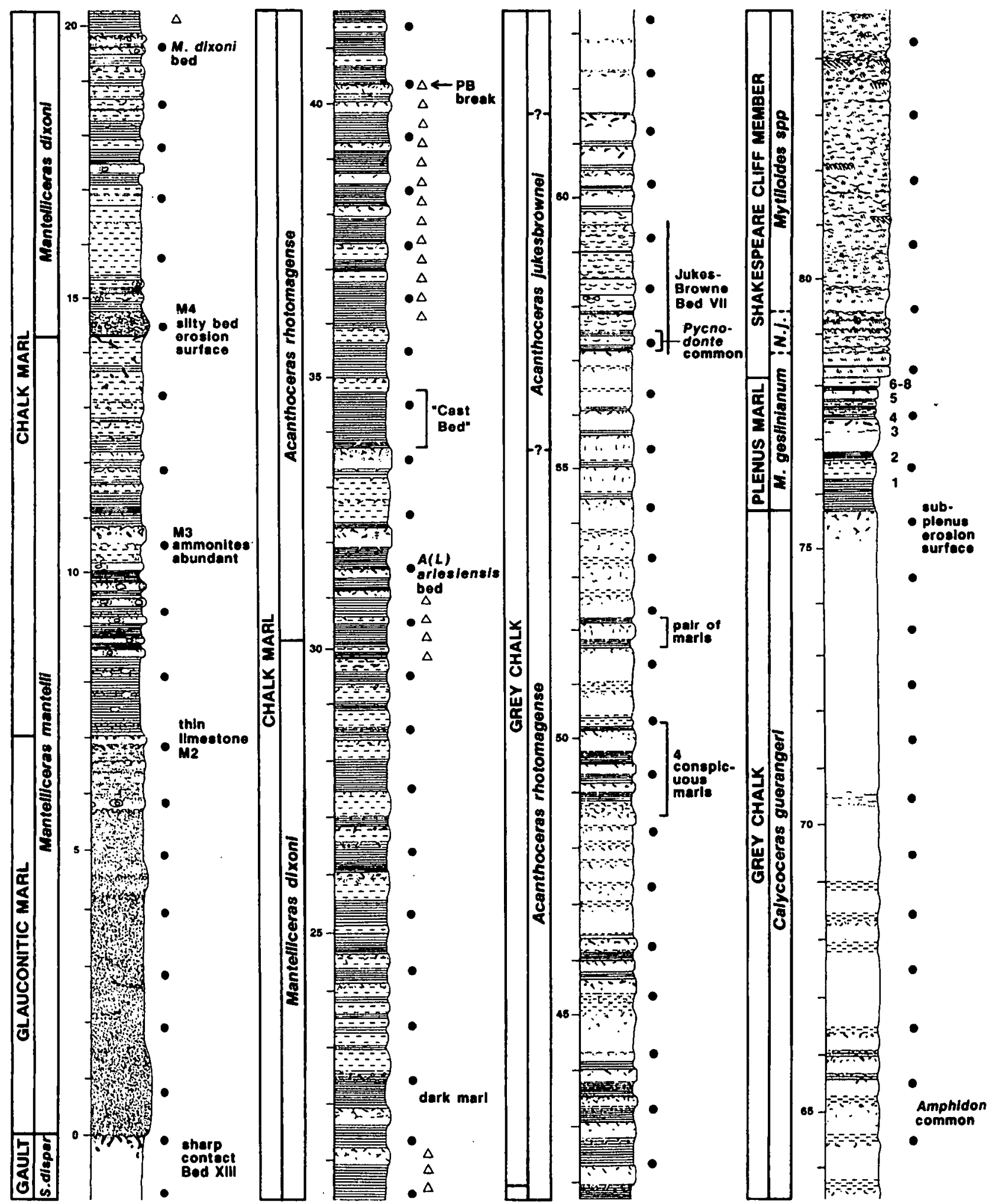

Figure 13. (a) For legend see p. 31. 
(b)

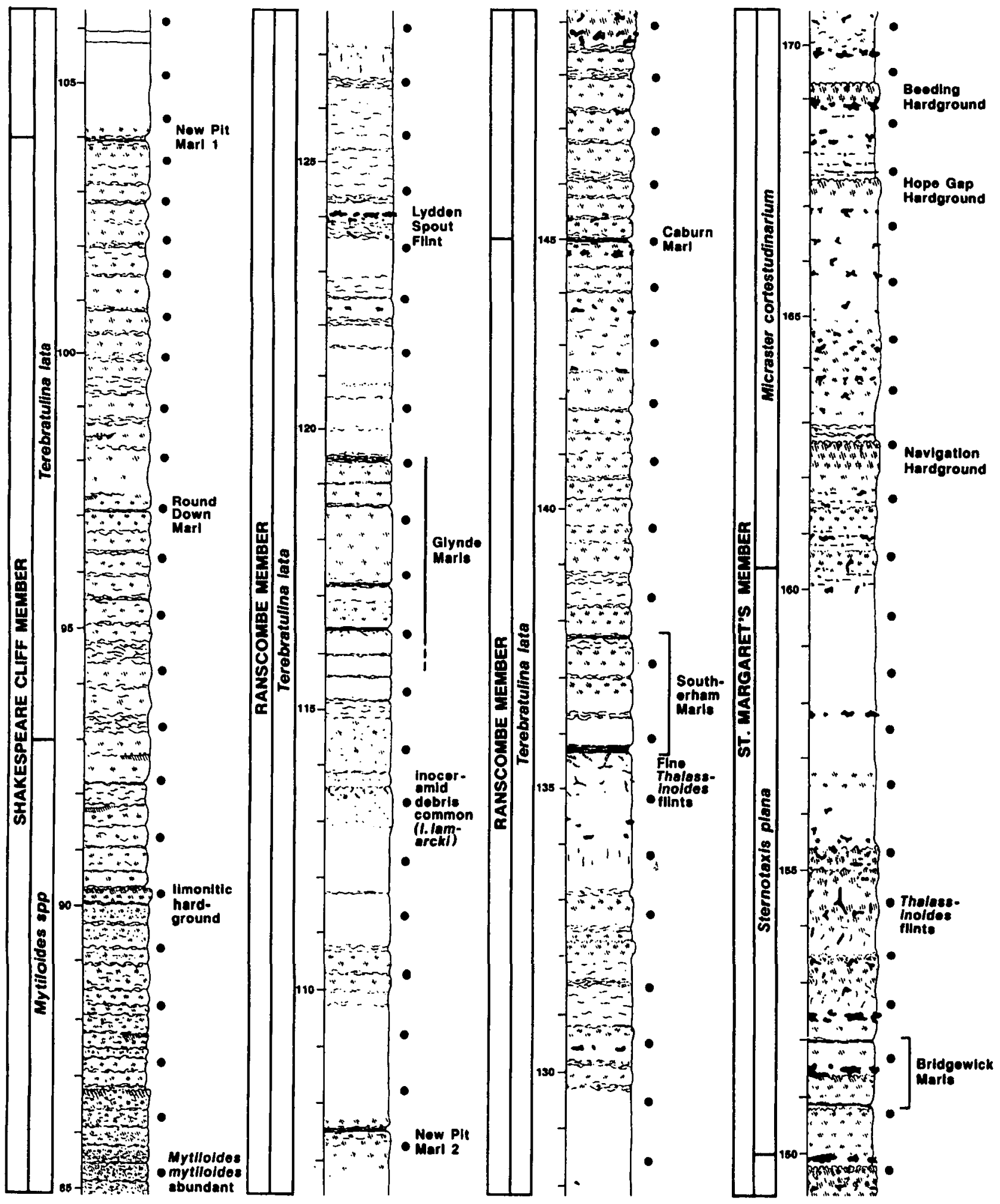

Figure 13. (b) For legend see p. 31. 
(c)

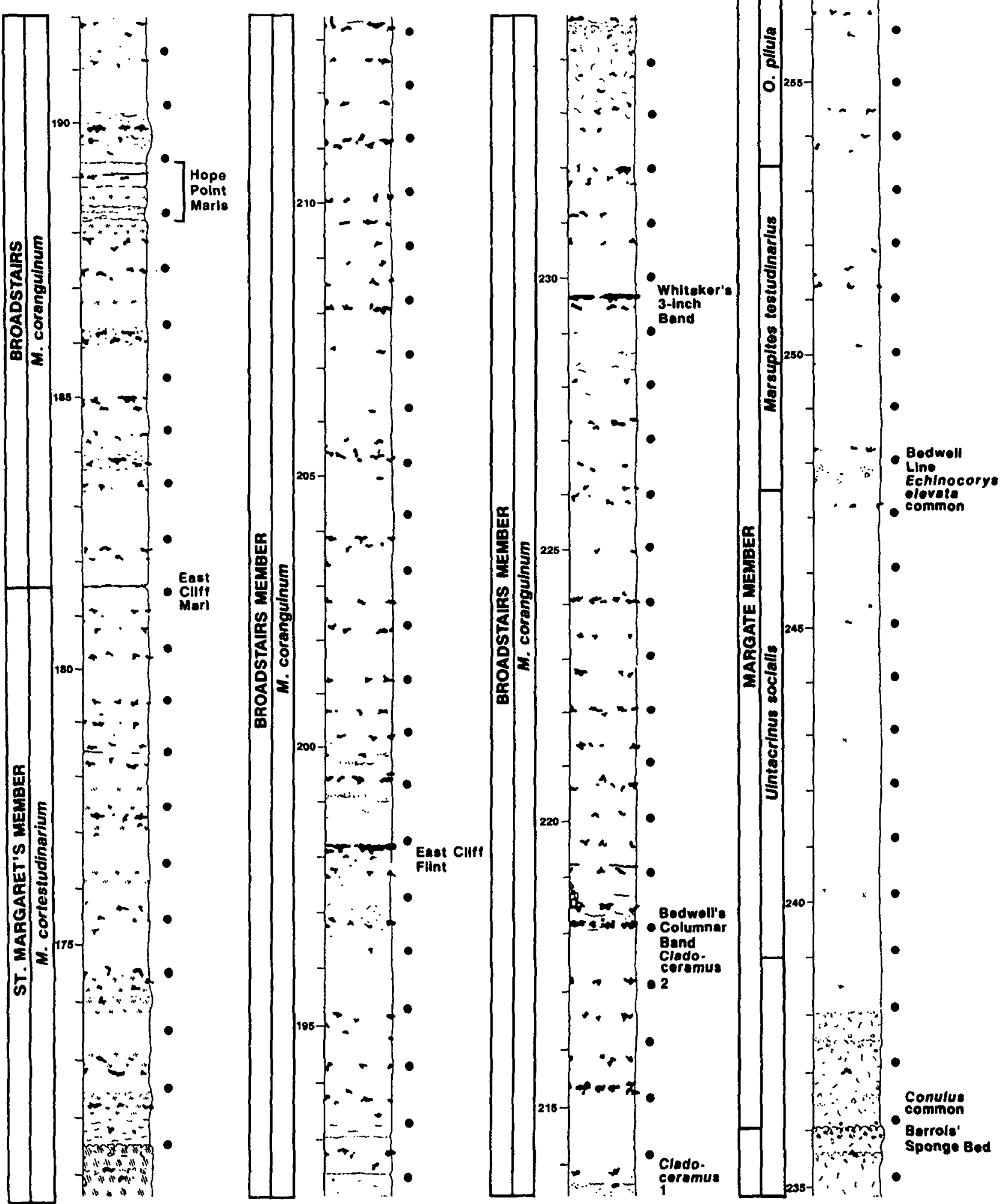

Figure 13. (a, b, c) Detailed lithological sections showing the levels from which the samples for isotopic analysis were obtained, East Kent. Samples taken at one-metre spacing wherever possible. 


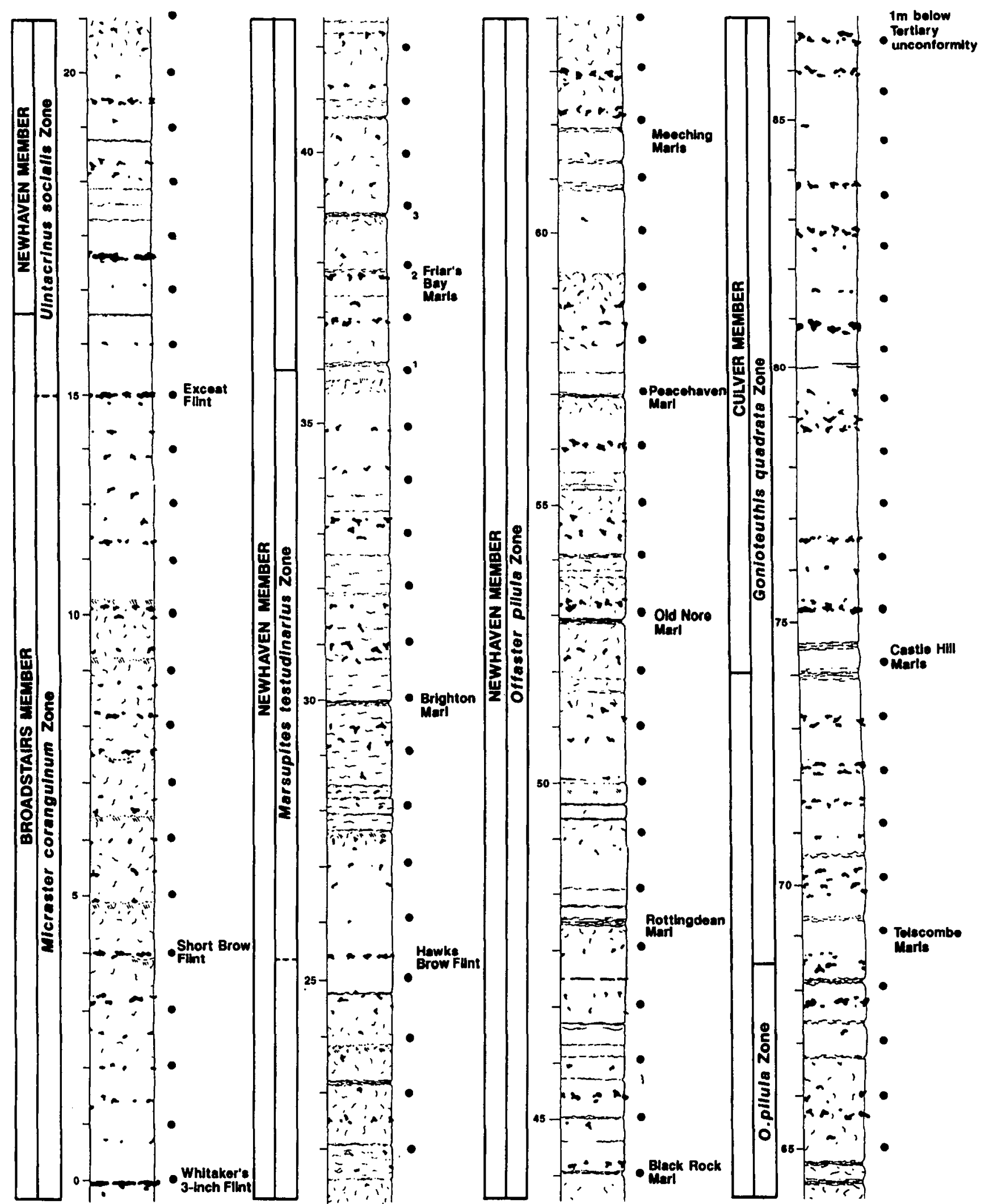

Figure 14. Detailed lithological sections showing the levels from which the samples for isotopic analysis were obtained, Seaford Head, Sussex. Samples taken at one-metre spacing wherever possible. 
(a)

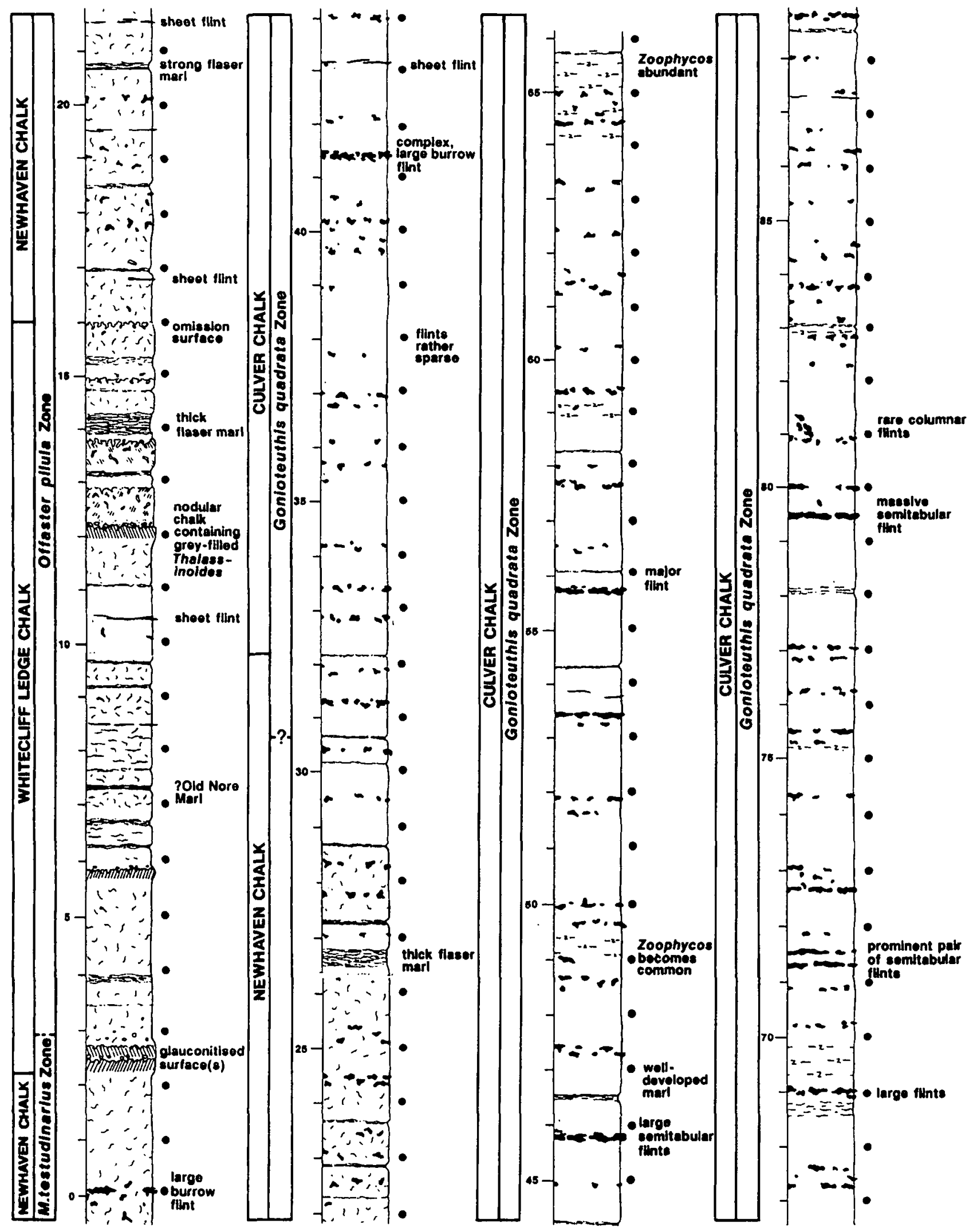

Figure 15. (a) For legend see p. 34. 
(b)

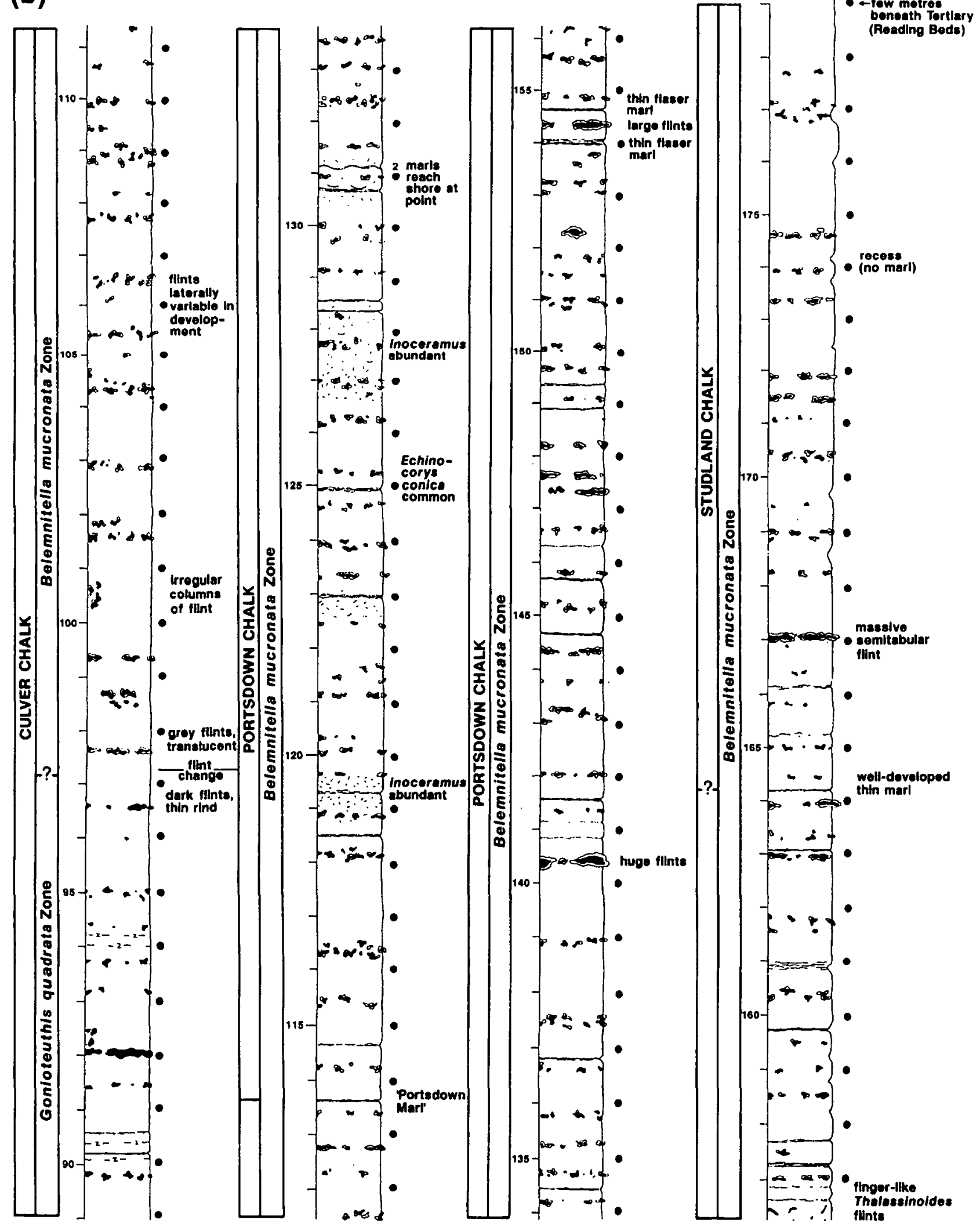

Figure 15. (a, b) Detailed lithological sections showing the levels from which the samples for isotopic analysis were obtained, Culver, Isle of Wight. Samples taken at one-metre spacing wherever possible. The southern point of the first bay is at about $-5 \mathrm{~m}$ on our log and the northern point at about $130 \mathrm{~m}$. 